\title{
Reading Classics on Electronic Readers in Municipal Libraries
}

A Long-Lasting Experiment

Lire des classiques sur liseuse en bibliothèque municipale. Une expérience qui fait long feu

Leer los clásicos en lector electrónico en biblioteca municipal. Una experiencia que no llega a buen puerto

\section{Stéphanie Kellner}

Translator. Alba Simaku

\section{(2) OpenEdition}

\section{Journals}

Electronic version

URL: http://journals.openedition.org/bssg/484

DOI: $10.4000 /$ bssg.484

ISSN: 2490-9424

Publisher

Presses universitaires de Vincennes

\section{Electronic reference}

Stéphanie Kellner, "Reading Classics on Electronic Readers in Municipal Libraries", Biens Symboliques / Symbolic Goods [Online], 7 | 2020, Online since 20 November 2020, connection on 04 March 2021.

URL: http://journals.openedition.org/bssg/484 ; DOl: https://doi.org/10.4000/bssg.484 
BIENS

SYMBOLIQUES

SYMBOLIC

GOODS
SYMBOLIQUES

Revue de sciences sociales sur les arts, la culture er les ides
A Social Science Journal on Arts. Culture and Ideas SYMBOLIC $\infty 2$ GOODS

is leurs racine tra

It des cassolettes d'encens et'finim

fums à la fois. Tout rit, chonte et

loucement ivre. Le printemps est

e; le soleil aide à faire patienter

des êtres qui n'en demandenit pas

gui, ayant l'azur du ciel, disenf

absorbés dans le prodige, jpuisant

la nature l'indifference du bien 2

ateurs du cosmos radieusement dist mi ne comne $n^{\circ} 7 / 2020$ as amion shasm

\section{Lire en numérique} Digital Readings 
Lire des classiques sur liseuse en bibliothèque municipale

Une expérience qui fait long feu
Reading Classics on Electronic Readers in Municipal Libraries

A Long-Lasting Experiment

\section{Stéphanie Kellner}

traduction | translation

Alba Simaku

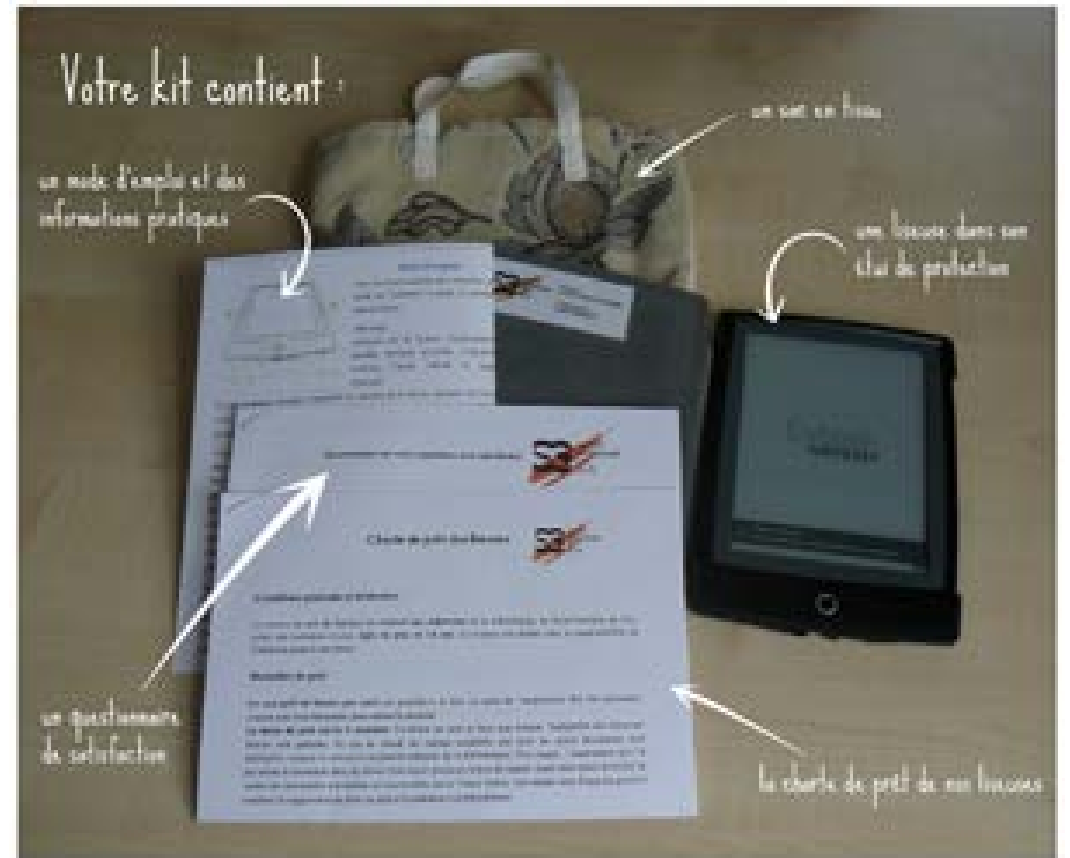

Fig. 1. Kit de prêt de liseuse / E-book lending kit 


\section{Introduction}

En janvier 2013, la bibliothèque municipale classée d'une commune de province expérimente auprès de ses usager-ère-s le prêt de liseuses électroniques chargées de textes classiques. Elle est ainsi une des pionnières du développement des offres numériques dans les bibliothèques françaises. Encouragé par l'État ${ }^{1}$, le " numérique " apparaît dans les discours politiques comme une réponse possible à plusieurs problématiques qui animent les bibliothèques - baisse de la lecture, vieillissement et baisse de fréquentation : à l'instar du livre de poche dans les années 1970 et de l'audiovisuel dans les années 1980 (Passeron \& Grumbach 1985), il doit permettre de conquérir de nouveaux publics, plus jeunes et moins lecteurs. Dans la bibliothèque qui constitue le terrain de la présente étude, le multimédia et les nouveaux supports sont inscrits dans le projet d'établissement dès la création dans les années 1980. Après les supports audiovisuels et les cédéroms (Pedler \& Zerbib 2001), puis l'installation d'internet et la numérisation de fonds patrimoniaux, l'établissement amorce dès 2010 la mise en œuvre de sa " bibliothèque numérique ${ }^{2}$ » et introduit dès 2011 des liseuses électroniques ${ }^{3}$, qui s'adjoignent aux expérimentations de mise à disposition de tablettes numériques dans les espaces presse et jeunesse.

1. Par exemple, le programme incitatif « bibliothèque numérique de référence créé en 2010 (dans lequel n'entre pas la bibliothèque étudiée) a en outre comme objectif d'atteindre de nouveaux publics.

2. La bibliothèque numérique se présente, en termes de types de documents, selon une structure quasi analogue à la bibliothèque «physique » avec livres, presse et magazines, musique, vidéo, autoformation et des contenus pour la jeunesse.

3. Une première expérience échoue en 2012 avec des liseuses Bookeen en raison d'offres à destination des bibliothèques non satisfaisantes.

\section{Introduction}

In January 2013, a French municipal library experimented with lending electronic readers loaded with literary classics to its users. This library was a pioneer in developing digital services in French municipal libraries. "Digital media" is increasingly encouraged by the government ${ }^{1}$, and is appearing in political discourse as a possible answer to many issues that libraries are currently facing, such as decreasing reading, ageing users, and declining visitation numbers. Like paperbacks in the 1970s and audiovisual media in the 1980s (Passeron \& Grumbach 1985), digital media aims to attract new audiences, typically younger and less avid readers. In the library used for the present study, multimedia and other new media have been inscribed in the library's development project since it was founded in the 1980s. After audiovisual media and CDROMs (Pedler \& Zerbib 2001) followed by the arrival of the internet and the digitization of heritage funds, a "digital library"2 was put in place in 2010 and e-readers introduced from $2011^{3}$, adding to initiatives that provided digital tablets in media and youth spaces.

1. For instance, the "digital reference library" incentive programme created in 2010 (which does not include the library investigated for this study) aims to reach new audiences.

2. Regarding types of document, the digital library is presented similarly to the "physical" library with books, newspapers, and magazines, music, videos independent study and youth content.

3. A first experiment failed in 2012 with Bookeen e-readers because of unsatisfactory content for libraries. 
Les modalités de prêt de la liseuse à la bibliothèque

Les liseuses électroniques sont des appareils de lecture légers permettant de stocker un nombre important de livres numériques, connectables à internet et dotés de la technologie e-ink (encre électronique qui imite l'imprimé). Celles proposées au prêt, des modèles SONY Reader, intègrent dictionnaire, outil de prise de notes et de surlignage, et des fonctions comme le marque page ou le grossissement des caractères. Elles sont à cet égard analogues aux appareils concurrents de l'époque, mais non rétroéclairées. Leurs boutons de navigation situés au bas de l'écran les font considérer comme un bon compromis au «tout-tactile ». Lors du prêt, la liseuse est fournie dans un étui en plastique qui comporte en outre un cordon USB, le chargeur de l'appareil et quatre documents : la notice du constructeur ; une notice d'utilisation illustrée de quatre pages faite par la bibliothèque indiquant la marche à suivre pas à pas ; une fiche invitant les usager-ère-s à laisser leurs impressions ; et enfin, une charte qui précise les conditions générales, les modalités du prêt, l'inventaire de la pochette et requiert l'engagement de l'usager·ère à respecter le délai de prêt, rendre le matériel en l'état et rembourser le coût du remplacement de la liseuse en cas de détérioration.

Cependant, comme le reste des offres numériques, le dispositif expérimental du prêt de liseuses connaît un relatif échec, conformément au faible engouement général pour le «numérique » en bibliothèque souligné par la dernière enquête nationale sur les publics et les usages des bibliothèques ${ }^{4}$ - et ce malgré un public local spontanément favorable à l'expérimentation de la lecture

4. Enquête du ministère de la Culture et de la Communication sur les « Publics et usages des bibliothèques en $2016 »: 47$. [Consulté le 25 juillet 2019.]

\section{Library E-reader Lending Terms}

Electronicreadersarelightweightreadingdevicesthatcanstore alarge number of digital books. They connect to theinternet and use e-ink technology (an electronic ink which imitates print). The SONY e-readers available for borrowing contain a dictionary, a notetaking and highlighting tool, as well as functions such as bookmarking or bold characters. They are thus similar to other machines of the same time-period, but are not back-lit. Their navigation buttons at the bottom of the screen make them a good compromise to entirely tactile screens. The e-reader comes in a plastic case which also contains a USB cable, the charger and four documents: the manufacturer's instructions, an illustrated four-page user manual made by the library with step-by-step instructions; a form inviting users to share their opinion on the device; and a charter with General Terms and Conditions, lending terms and conditions, an inventory with the case contents requiring the user to respect the due date, to return the material in good condition, and to reimburse the cost of the e-reader in the event of damage.

However, similarly to other digital services, the experimental e-reader lending system was relatively unsuccessful, in tune with the general low popularity of digital media in libraries. This was again illustrated in the latest national survey on library audiences and usage ${ }^{4}$, despite a local audience naturally in favour

4. Survey by the Ministry for Culture and Communication on "Library use and audiences in 2016": 47. [Accessed on 25 July 2019.] 
numérique ${ }^{5}$. Comment comprendre ce décalage ? Comment la lecture numérique est-elle perçue par les usager·ère-s en amont et en aval de l'expérimentation ? Dans quelle mesure le dispositif lui-même (la liseuse, son contenu, les discours et pratiques qui les entourent et les conditions de l'expérimentation) joue-t-il dans les

perceptions et les usages ?

La localisation des liseuses dans les espaces territorialisés de la bibliothèque (Passeron 1982 : 72 ; Roselli \& Perrenoud 2010) la prédestine à certaines catégories d'usager-ère's (des adultes lecteur.rice-s de littérature) plutôt qu'à un public élargi : les vingthuit liseuses ne sont disponibles que dans l'espace où sont regroupées les collections littéraires à destination des adultes ; elles sont accessibles sur demande (et en théorie une seule fois) pour les usager $\cdot$ ère $s$ majeurs inscrits à la bibliothèque ${ }^{6}$. Le contenu des liseuses est riche (trois cent soixante-cinq livres numériques) mais restreint à des textes appartenant au domaine public, qui relèvent principalement de la littérature classique : on n'y retrouve donc pas la diversité des choix possibles de lecture rencontrés en bibliothèque municipale. Au moment de l'enquête, des contraintes juridiques et techniques et la rareté des offres à destination des bibliothèques sont les éléments d'explication invoqués pour justifier cette offre ${ }^{7}$. Choisie pour son caractère indiscutable et ces raisons pratiques, une telle offre ne correspond d'ailleurs pas

5. Stéphanie Kellner, Le Numérique en médiathèque. Entre mythes et réalités. Thèse soutenue le 13 mars 2020.

6. La restriction de l'âge et la limitation à un seul emprunt de la liseuse n'ont pas été strictement appliquées. Toutefois, très peu d'usager-ère.s ont emprunté la liseuse deux fois, et très peu avaient moins de dix-huit ans.

7. Par exemple, le flou législatif autour du prêt numérique en bibliothèque et la contrainte de l'accès aux livres numériques due aux Droits de reproduction mécanique (DRM). À noter que le dispositif « Prêt umérique en bibliothèque (PNB) est lancé plus tard, en 2014 (la bibliothèque étudiée n'y entre pas). of experimenting with digital reading ${ }^{5}$. How should this disparity be interpreted? How is digital reading perceived by users before and after the current experiment? To what extent does the actual medium (the e-reader, its content, the discourse and practices that surround it and the conditions of the experiment) play into its perception and use?

E-readers are situated in specific library spaces (Passeron 1982: 72; Roselli \& Perrenoud 2010) which designate their use to certain user categories (adult literature readers) rather than to a larger audience. The twenty-eight e-readers are only available in the space dedicated to literary collections for adults; they are accessible on demand for adult users registered at the library (and in theory, only once) ${ }^{6}$. Their content is rich (three hundred and sixty five digital books), but is restricted to public domain texts, mainly classics. They do not contain the diversity of possible reading choices found in the municipal library. At the time of the survey, the arguments used to justify this offer included judicial and technical constraints and the scarcity of lending possibilities for libraries ${ }^{7}$. Chosen for its indisputable character and practical advantages, such an offer does not correspond to what the librarians, who are most likely to support digital devices, wish to promote. Indeed, a

5. Stephanie Kellner, Digital in Public Library. Between Myths and Realities Thesis defended on 13 March 2020.

6. Age restrictions and the restriction to borrow an e-reader one-time only were not strictly enforced. However, very few users borrowed the e-reader twice, and very few were under eighteen years old.

7. For instance, the legislative blur around lending digital devices in libraries and the constraints on access to digital books due to mechanical reproduction rights. Note that the "Digital Lending in Libraries" (Prêt numérique en bibliothèque) initiative was launched later on, in 2014 (the library in question did not participate) 
particulièrement à ce que souhaitent défendre les bibliothécaires les plus portés à soutenir un dispositif numérique, un principe de division entre les anciens et les modernes continuant à structurer les équipes des bibliothèques (voir Rabot 2011 : 167-172) ${ }^{8}$.

La définition de l'offre ne peut cependant suffire à expliquer cet échec des liseuses. Jean-Claude Passeron soulignait, au sujet de l'audiovisuel dans les années 1980, le risque d'inscrire "l'analyse de la consommation culturelle dans l'illusion de l'abstraction économiste d'un marché où offre et demande se confrontent abstraitement » (Passeron 1982 : 72). Selon l'auteur, il n'existe pas de définition d'un moyen de communication indépendante des définitions sociales de son usage, chacune ayant à reconnaître la loi hiérarchique de la "légitimité culturelle ${ }^{9}$. C'est dans cette perspective d'étude que ce dispositif a constitué un terrain d'observation au cours de la phase exploratoire de l'enquête.

Dix mois après le lancement de l'expérimentation, cette « enquête dans l'enquête » a recouru au recueil et traitement de données statistiques sur les emprunteur.se's de liseuses (données d'emprunts reliées à des variables sociologiques - sexe, âge, profession déclarée au moment de l'inscription, lieu de résidence), à des observations de dispositifs de médiation mis en œuvre par les bibliothécaires autour de ces liseuses, et à des entretiens semidirectifs avec vingt-quatre des usager-ère-s-emprunteur·se·s. Les

8. Cécile Rabot propose quatre modèles idéal-typiques du métier de bibliothécaire, auxquels peuvent être associés des types d'offres: A-conservateurs/collectionneurs (modèle plus disposé à porter une offre littéraire classique) ; B-pédagogues/militants ; C-découvreurs/passeurs (modèle qui porte le dispositif de la liseuse) ; D-suivistes/vendeurs.

9. Depuis La Distinction (Bourdieu 1979) de nombreuses enquêtes ont sur ce point contribué à démontrer le poids des hiérarchies culturelles. On pense ici par exemple aux travaux de Gérard Mauger, Bernard Lahire, Philippe Coulangeon et Wenceslas Lizé. division principle between older and more modern librarians still structures library staff (see Rabot 2011: 167-172) ${ }^{8}$.

The presentation of the digital services initiative does not, however, suffice to explain why the e-readers were unsuccessful. With regards to audiovisual media in the 1980s, Jean-Claude Passeron underlined the risk of inscribing "the analysis of cultural consumption into the illusion of economic abstraction by a market where offer and demand are abstractly confronted" (Passeron 1982: 72). According to the author, there is no definition of an independent means of communication that does not rely on the social definitions of its use, each must recognize the hierarchical law of "cultural legitimacy" It was in this study perspective that this measure constituted an observation field during the exploratory phase of the survey.

Ten months after launching the experiment, the "survey in a survey" started to collect and process statistical data about e-reader borrowers (borrowing data related to sociological variables-gender, age, declared profession upon registration, place of residence) to observe mediation measures put in place by librarians concerning e-readers, as well as to conduct semi-directive interviews with twenty-four of the user-borrowers. The written commentaries left after the experiment were also taken into account.

8. Cécile Rabot put forward four ideal models that typify the librarian profession to which one can associate types of offers: A-conservators/collectors (a model that is more disposed to offer classics); B-Educators/activists; C-Discoverers/ setters (model which carries the e-reader device); D - Followers/sellers.

9. Since Distinction (Bourdieu 1979), many have contributed to demonstrating the weight of cultural hierarchies. For instance, Gérard Mauger, Bernard Lahire, Philippe Coulangeon, and Wenceslas Lizé. 
commentaires écrits laissés à l'issue de l'expérience ont également été pris en considération.

L'objectif de cette démarche était d'abord d'identifier le(s) public(s) de la liseuse électronique tant du point de vue de leurs caractéristiques sociales que de leurs habitudes culturelles à l'intérieur et en dehors de la bibliothèque. Ensuite, il s'agissait de comprendre les mécanismes sociaux sous-jacents à la pratique de la lecture sur la liseuse empruntée, telle que l'expérimentation la proposait, (ou à son absence) et les conditions sociales de sa réception. Existe-t-il une cohérence dans les préférences culturelles des publics selon les supports proposés par la bibliothèque ? À l'intérieur du groupe constitué par les lecteurs et lectrices, le « numérique » peut-il induire des variations dans les préférences de genres littéraires ? Que révèlent les analyses de trajectoire et des modes de socialisation pour la compréhension de cette pratique?

Cet article tentera de répondre à ces questionnements en présentant dans un premier temps les raisons qui poussent les usager ère-s à emprunter la liseuse. II s'agira de montrer que cette démarche est socialement classante et associée à la bonne volonté culturelle, et qu'elle met en jeu des logiques générationnelles et de mise en scène de soi au travers de compétences numériques. Dans un second temps, il s'agira de présenter les intérêts portés à l'appareil et qui expliquent tant l'engouement de cette minorité d'usager·ère's que les limites qu'il présente pour la pratique de lecture.
The aim of this approach was first of all to identify the audience(s) of electronic readers, both from the point of view of their social characteristics as well as from their cultural habits inside and outside the library. Thereafter, we wanted to understand the social mechanisms underlying reading practices on borrowed e-readers, in the way that the experiment presented it, (or its absence) as well as the social conditions of its reception. Is there any consistency in the audiences' cultural preferences according to the devices on offer in the library? Inside the group constituted by readers, can digital devices instigate fluctuations in literary genre preferences? What does the analysis of trajectory and socialization modes reveal in our understanding of this practice?

This article will attempt to answer the above questions, first of all by presenting the reasons that drive users to borrow e-readers. We aim to show that these devices are socially classifying and associated with cultural goodwill, and that generational and self-representation rationales come into play through the use of digital skills. We will then illustrate the interest shown towards these devices, and how this explains their strong attraction for a small number of users as well as their limits for reading. 


\section{Méthodologie}

La bibliothèque prise comme cas d'étude est une bibliothèque municipale à vocation régionale (BMVR10) implantée dans une commune d'environ cent quarante mille habitants, située sur un territoire à dominante rurale. La bibliothèque est structurée en réseau autour de six sites : une bibliothèque centrale en centre-ville et cinq annexes en périphérie. Le matériau empirique exploité concerne principalement les emprunteur-se-s de la liseuse électronique mais s'intègre dans un ensemble de données plus large, recueilli au cours de la recherche doctorale. Celle-ci s'est déroulée en plusieurs phases et a mobilisé plusieurs techniques d'enquête pour l'étude des publics qui en constitue un des axes. Une phase exploratoire a mobilisé l'observation directe des publics. Des observations ont été menées « tous azimuts " dans l'ensemble de la bibliothèque, complétant un travail réalisé en Master sur les " séjourneurs et séjourneuses » de la bibliothèque. Des observations " ciblées » ont été conduites dans les espaces informatisés (ateliers informatiques, ordinateurs en accès libre), lors de médiations numériques et toute autre manifestation en lien avec le numérique (conférences et expositions). Cette phase a permis le recueil des données concernant les emprunteur.se's de la liseuse (cent quatre-vingt dix-neuf individus au moment du relevé), ainsi que des commentaires laissés par des usager-ère-s après leur emprunt de la liseuse (Kellner 2017a). Les observations " ciblées » se sont poursuivies au-delà de cette phase exploratoire.

10. Douze BMVR ont été créées en France dans le cadre d'un dispositif particulier mis en place par l'État de 1992 à 1997. Celui-ci ouvrait droit à des financements pour équiper des communes dont les bibliothèques municipales pouvaient répondre à des critères spécifiques en termes de volume de collection, de taille et de formation professionnelle, dans le but de renforcer le maillage territorial à partir des capitales régionales.

\section{Methodology}

The case study was carried out in a town with a regional library 10 situated in a municipality of around 140,000 inhabitants in a mainly rural area. The library is composed within a network of six sites: one central library in the town centre and five annexes on the outskirts. The empirical data used mainly concern e-reader borrowers but are embedded in a larger data set, collected during doctoral research. This research took place over several phases and used various survey techniques in order to study the audience that constitutes one of the research angles. An exploratory phase involved directly observing the audiences. Wide-ranging observations were carried out throughout the whole library, completing my master's research on library "residents". "Targeted" observations were conducted in computerized spaces (computer workshops, open access computers, etc.) during digital mediations and all other events linked to digital media (conferences and exhibitions). This phase enabled data collection on e-reader borrowers (one hundred and ninety-nine individuals at the time of the survey), as well as comments left by users after they borrowed the e-reader (Kellner 2017a). The "targeted" observations continued after this exploratory phase. A questionnaire was carried out in 2014 among the audiences of the whole network-members and nonmembers alike-over a two-month period $(\mathrm{N}=1996)$. The questionnaire solicited users of at least one of the library's services, whether on-site or at a distance, and comprised six sections: library attendance; library uses and practices;

10. Twelve regional libraries were created in France as part of a specific initiative put in place by the government from 1992 to 1997 . It granted the right to financial aid to equip town libraries that corresponded to specific criteria in terms of collection volume, size, and professional education, with the aim of strengthening the area's network from the regional capitals. 


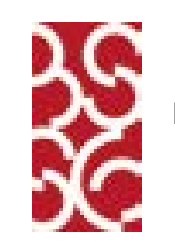

Une enquête par questionnaire a été réalisée en 2014 auprès des publics de l'ensemble du réseau - inscrits ou non - sur une période de deux mois $(N=1996)$. Le questionnaire sollicitait les utilisateurs et utilisatrices d'au moins un service de la bibliothèque sur place ou à distance et comprenait six sections : fréquentation de la bibliothèque, pratiques et usages dans la bibliothèque, pratiques et usages du « numérique » de la bibliothèque, autres pratiques culturelles (hors bibliothèque), équipement du foyer, propriétés sociales. Le questionnaire ayant été créé en versions papier et dématérialisée, la passation reposait sur un dispositif multiple : face à face, distribution aux usager ère-s, proposition du questionnaire en accès libre, et mise en ligne. La passation en face à face et la distribution ont été conduites en portant une vigilance particulière aux espaces pouvant être fréquentés par des non-inscrits. Le lien permettant d'accéder au questionnaire en ligne a été transmis par email à tous les usager ère-s s'étant inscrit·e.s au moins une fois à la bibliothèque depuis son ouverture en 1998 et dont l'adresse email était valide. $87 \%$ des enquêté e.s ont répondu en ligne (Kellner 2017b). Une série de vingt-quatre entretiens a été menée avec des usager-ère·s ayant emprunté la liseuse et ayant répondu favorablement à ma sollicitation - transmise par l'envoi d'un email par la bibliothèque aux emprunteur.se-s disposant d'une adresse valide. La grille d'entretien abordait : l'emprunt de la liseuse, la fréquentation de la bibliothèque, les pratiques culturelles en dehors de la bibliothèque, les modes de socialisation à la lecture et aux nouvelles technologies, les trajectoires sociale, scolaire et professionnelle. La structure des emprunteur.se·s rencontré.e.s est la suivante : neuf hommes et quinze femmes, dont treize

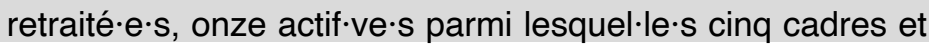

practices and usage of the library's "digital" aspects; other cultural practices (outside the library); home equipment; and social properties. The questionnaire had both paper and online versions; its distribution depended on multiple measures: face to face; delivery to users; an open access questionnaire proposal; and online use. The face-to-face distribution and delivery happened with special care given to spaces which non-members could visit. The link to the online survey was transmitted via email to all users who had registered at the library at least once since it opened in 1998 and whose email address was still valid. Eighty-seven per cent of those surveyed answered online (Kellner 2017b). A series of twenty-four interviews were carried out with users who had borrowed the e-reader and responded to my request positively - a request transmitted by the library via email to all borrowers with a valid email address. The interview grid broached various topics: e-reader borrowing, library attendance, cultural practices outside the library, social adaptation modes towards reading and new technology, and social, schooling, and professional trajectories. The borrowers that I met were nine men and fifteen women, thirteen of whom were retired, eleven were professionally active, five of whom were executives and belonged to higher intellectual professions, three came from intermediary professions, and three were without any professional activity (one unemployed and two students). 
professions intellectuelles et supérieures, trois professions intermédiaires, trois personnes sans activité professionnelle (une sans profession et deux étudiant·e·s)

\section{L'emprunt de la liseuse en bibliothèque municipale : des enjeux de classe sociale et de génération}

\subsection{La bonne volonté culturelle à l'origine de l'emprunt} de la liseuse

Les profils culturels des usager-ère-s ayant emprunté une liseuse électronique à la bibliothèque attestent de leur " bonne volonté culturelle ", qui s'exprime selon Pierre Bourdieu par une docilité culturelle et un goût pour les spectacles éducatifs ou instructifs. Les membres des classes moyennes ont en commun d'occuper une position moyenne dans l'espace social et partagent un habitus « petit bourgeois » fondé sur une volonté d'ascension sociale. Celle-ci se traduit par l'imitation des pratiques de la classe dominante et une mise à distance de celles qui caractérisent les classes populaires. Elle s'observe aussi dans un respect profond de l'ordre établi et dans le partage entre goûts d'inclination et goûts de volonté (Bourdieu 1979 : 365-431). Bernard Lahire ajoute qu'en raison de leur position intermédiaire dans les rapports sociaux et de leurs propriétés culturelles contradictoires, les classes moyennes peuvent tout autant que les autres classes sociales être le lieu de la consommation de genres dits moyens, mais présentent toutefois plus fréquemment des profils culturels dissonants avec « autant de chances d'être caractérisés par des profils consonants à tendance légitime $(5,4 \%)$ que par des profils dissonants à tendance peu légitime $(7,8 \%)$ » (Lahire 2006). Par leur position, leur trajectoire sociale souvent ascendante, leurs goûts culturels, ou encore leur

\section{Borrowing E-Readers from Town Libraries: Social class and Generational Stakes}

\subsection{Cultural Goodwill at the Root of E-Reader Borrowing}

The cultural profiles of readers who borrowed an e-reader from the library attest to their "cultural goodwill," which, according to Pierre Bourdieu, is expressed by cultural acquiescence and a taste for educational or informative plays or shows. Middle class people share the fact that they occupy an intermediate position in the social sphere and share a "petit bourgeois" habitus founded on the dream of upward social mobility. This translates into imitating ruling class practices and distancing oneself from those that characterize the working class. It can also be observed by a profound respect for the established order and a sharing of "tastes they incline to" and "tastes they aspire to" (Bourdieu 2013). Bernard Lahire adds that, due to their intermediary position in social interactions and their contradictory cultural properties, the middle classes can, just as well as other social classes, be a space for so-called "average" types of consumption. However, they more often display cultural profiles that are dissonant: they have "just as much chance of being characterized as consonant profiles with a legitimate tendency $(5.4 \%)$ as dissonant profiles with a less legitimate tendency (7.8\%)" (Lahire 2004). Through their position, their mainly upward social trajectory, cultural tastes, or their relationship to culture, e-reader users define themselves by this "cultural goodwill." This helps to 
rapport à la culture, les usager-ère-s de la liseuse se définissent par cette " bonne volonté culturelle » qui constitue un élément explicatif de l'emprunt de la liseuse électronique à la bibliothèque comme mode d'acquisition de la culture.

1.1.1. Trajectoires sociales ascendantes et goûts culturels «moyens"

Le groupe des cent quatre-vingt-dix-neuf emprunteur-se-s de liseuses n'est pas parfaitement homogène, mais des tendances se dégagent dans sa structure : il s'apparente au public majoritaire de la bibliothèque et appartient plutôt à la fraction intellectuelle des classes moyennes supérieures regroupant cadres de la fonction publique, professions intellectuelles, artistiques et libérales. Comme le public de la bibliothèque, ces usager-ère-s apparaissent majoritairement sous lestatut de «cadre etprofessions intellectuelles supérieures 》 $(29,2 \%)$ et de «professions intermédiaires » $(18,5 \%)^{11}$. La reconstitution des trajectoires sociales à partir des vingt-quatre entretiens permet d'approfondir ces données en révélant une diversité des trajectoires, souvent ascendantes (inter ou intra classe), par le biais de la qualification ou par un avancement donnant accès à un statut professionnel supérieur. À l'instar du public de la bibliothèque, les femmes sont plus nombreuses sans être pour autant surreprésentées. En revanche, avec 56,3\% de 50 ans et plus (contre $48,7 \%$ à la bibliothèque), les individus ayant emprunté la liseuse sont majoritairement à la retraite ou dans la dernière décennie de leur activité professionnelle et une

11. Ces données sont recueillies par la bibliothèque au moment de la première inscription et ne sont pas mises à jour ni davantage précisées (Kellner 2017a). Un flou demeure donc sur les emplois exercés, la part que représentent les retraité.e.s et la profession qu'ils/elles ont exercée. Le questionnaire ne permet pas de compléter car les individus ayant emprunté une liseuse ne représentent qu' $1,3 \%$ des répondant·e.s $(N=1985)$. define the practice of borrowing e-readers from the library as a mode of cultural acquisition.

\subsubsection{Ascendant Cultural Trajectories and "Average" Cultural Taste}

The group of 199 e-reader borrowers is not perfectly homogenous but shares certain tendencies. It is akin to the library's main audience and belongs rather to the intellectual fraction of the upper middle classes, which includes public officials and intellectual, artistic, and liberal professions among its members. Just like the library audience, these users mainly appear in the "executives and higher intellectual" (29.2\%) and "intermediary" (18.5\%) professional categories ${ }^{11}$. The reconstitution of social trajectories from the twenty-four interviews allows us to refine this data, revealing a diversity of trajectories, often upwardly mobile (inter or intra class), through qualifications or a promotion giving access to a higher professional status. Like the library audience, many of the respondents were female, but women are nonetheless not overrepresented. However, with more than $56.3 \%$ who are over 50 years old (compared to $48.7 \%$ at the library), the individuals who borrowed e-readers are mostly retired or in the last decade of their professional activity, and an overrepresentation of 50-59 year-olds allows us to distinguish them from the library's general audience (Kellner 2017a).

11. These data are collected by the library upon first registration and are not updated or further specified (Kellner 2017a). Uncertainty remains around the issue of employment: the proportion of retired users and their former profession. The questionnaire did not allow me to complete these data because the individuals who borrowed an e-reader only represented $1.3 \%$ of respondents $(\mathrm{N}=1985)$. 
surreprésentation des 50-59 ans permet de le distinguer du public global de la bibliothèque (Kellner 2017a).

Ces usager·ère-s ont pour autres propriétés communes une multiplicité de pratiques culturelles. Avec la diversification de l'offre en bibliothèques municipales, s'observent pourtant des différenciations, quantitatives et qualitatives, dans les manières de consommer cette offre. Certain'e.s recourent uniquement à l'espace ; d'autres multiplient les pratiques, avec une intensité variable $^{12}$ (Passeron \& Grumbach 1989). La fréquentation d'une bibliothèque municipale traduit pour eux/elles le souhait de se cultiver et s'ajoute à cet égard à l'usage d'autres établissements culturels (théâtre, cinéma, et pour certains opéra, concerts) et parfois à un investissement associatif. De surcroît, les emprunteur.se-s de liseuses fréquentent la bibliothèque régulièrement et assidûment, témoignant d'une curiosité certaine pour les propositions de l'établissement. Fort·e.s lecteur.rice-s comme le tiers du public de la bibliothèque, ils/elles témoignent des pratiques dominantes dans l'établissement : empruntant régulièrement, principalement des livres (qui représentent $62 \%$ de leurs emprunts), mais aussi des DVD et des documents sonores. En fait, $80 \%$ d'entre eux/ elles empruntent plusieurs types de supports. Ils/elles multiplient par ailleurs les activités à la bibliothèque : projections de films, conférences, concerts, expositions, ateliers multimédias, clubs

lecture.

12. Les auteurs proposent d'affiner le regard porté sur les pratiques culturelles en se penchant sur les lois qui en déterminent l'intensité. Ils font émerge de l'enquête une typologique de publics qui se distinguent par la variation et l'intensité de leurs usages, et dont les deux figures idéaltypiques extrêmes de cette typologie sont les passagers (qui passent seulement pour emprunter et restituer des documents) et les séjourneurs (qui restent et passent du temps sur place)
These users have many cultural practices in common. However since town library services are becoming increasingly diverse, qualitative and quantitative differences can be noted, particularly in the way these services are used. Some only use the space; others have a variety of practices with varying intensity (Passeron \& Grumbach 1989$)^{12}$. Visiting a town library often indicates the desire to be cultivated and is often combined with other cultural establishments (theatre, cinema, as well as operas and concerts for some) and sometimes volunteer work. Furthermore, e-reader borrowers attend the library regularly and assiduously, and are curious about what the establishment has to offer. Like a third of the library's audience, they are avid readers and testify to the library's main practices: they borrow regularly, mainly books (which represent $62 \%$ of all borrowed items), but also DVDs and audio documents. In fact, $80 \%$ of them borrow several types of media. Moreover, they use the library for various purposes: film projections, conferences, concerts, exhibitions, multimedia workshops, book clubs.

12. The authors suggest refining their gaze on cultural practices by taking a closer look at the laws that determine their intensity. Through the survey, an audience typology emerges that is distinguished by variation and intensity of use. The two extreme ideal types in this typology are passers-by (who simply call by to borrow and return documents) and residents (who stay and spend time onsite). 
Leurs goûts littéraires déclarés en entretien présentent une palette variée de genres lus qui oscillent d'un pôle à l'autre de la hiérarchie des légitimités : romans, notamment sentimentaux, littérature de terroir, livres pratiques, d'arts de vivre ou de loisirs, romans policiers ou fantastiques, bandes dessinées, mangas, ou encore essais politiques et philosophiques. Ils/elles ne sont ni complètement populaires ni complètement légitimes et varient entre goûts d'inclination et goûts de volonté. Certain·e.s sont plutôt tourné·e·s vers des genres moyens comme M. D., 33 ans, infirmier, qui mêle littérature fantastique, romans policiers, et bandes dessinées. D'autres ont des profils consonants à tendance plutôt légitime ou des profils dissonants. Mme M., 65 ans, retraitée psychologue à la protection judiciaire de l'enfance, issue d'un milieu modeste, déclare papillonner entre romans, livres de développement personnel et livres pratiques.

Mme T., 70 ans, retraitée issue des classes populaires, et deuxième enfant d'une fratrie de huit filles, explique que sa mère aimait lire et que contrairement à ses sœurs qui « lisent pas du tout et qui aiment pas lire... moi, j'ai toujours aimé lire ». Si elle était ouvrière, ses vingt dernières années de travail étaient dans l'atelier de reliure d'une bibliothèque parisienne qui lui ont donné un accès privilégié au monde du livre, à la lecture et aux bibliothèques. Elle présente un profil culturel dissonant où les pratiques oscillent d'un pôle de légitimité à l'autre. Elle écoute du jazz, de la musique classique et de la chanson française. Elle lit beaucoup : polars, romans, traités, biographies, "livres pour apprendre », articles de société dans la presse féminine, plus rarement la presse quotidienne et plutôt locale. Elle fréquente peu d'établissements culturels mais va au cinéma et, chaque semaine, à la bibliothèque. Elle y fait partie d'un club lecture, fréquente l'atelier multimédia, visite les expositions (mais ne vient ni pour les concerts ni pour les conférences) et emprunte des documents (livres, $C D$, textes enregistrés). Elle achète par
Their literary tastes disclosed in interviews present a varied palette of genres, oscillating from one end of the legitimacy hierarchy to the other: novels, mainly romantic ones, regional literature, DIY books, lifestyle and hobby books, crime or fantasy novels, comics, manga, and political and philosophical essays. They are neither entirely popular nor completely legitimate and vary between "tastes they incline to" and "tastes they aspire to" (Bourdieu 2013). Some are more geared towards standard genres, such as Mr D., a 33-yearold nurse, who mixes fantasy literature, crime, and comics. Some have consonant profiles with a rather more legitimate tendency or dissonant profile. Mrs M., a 65-year-old retired psychologist for child legal protection from a modest background, says that she flits between novels, self-help, and DIY books.

Mrs T. (a 70-year-old working class retiree, the second of eight sisters) explains that her mother liked to read and that unlike her sisters, who "do not read and do not like to read... I myself have always liked to read." Although she has been employed in manual labour, the last twenty years of her working life were spent in a bookbinding workshop in a Parisian library, which gave her privileged access to the world of books, reading and libraries. She has a dissonant profile; her practices oscillate from one pole of legitimacy to the other. She listens to Jazz, classical music, and French pop. She reads a lot: crime; novels; textbooks; biographies; "educational books;" and social articles in women's magazines; and reads local newspapers more than national dailies. She goes to few cultural establishments but visits the cinema and the library every week. She is part of a book club, goes to multimedia workshops, attends exhibitions (but does not go to concerts or conferences) and borrows items (books, CDs, and audiobooks). She also buys second-hand books from charity shops and new 
ailleurs des livres d'occasion dans des structures associatives et des livres neufs dans les librairies indépendantes. Elle conserve d'ailleurs peu ses livres qu'elle donne/rapporte aux associations. Elle porte des jugements légitimistes sur ses pratiques et rejette la culture " commerciale » - manifestant sans doute aussi une solidarité de corps avec les métiers du livre : «Alors, j'ai découvert, je ne devrais pas le dire, mais à Leclerc, là, ils ont une très très grande librairie, qui est très intéressante, et c'est facile d'accès.. Ben parce que ce n'est pas un libraire indépendant... ". Elle met à distance certaines productions et en valorise d'autres : " Je lisais des romans à l'eau de rose à l'adolescence, je m'en rappelle plus. Les polars, c'est où je travaillais à la bibliothèque et avec quelques bibliothécaires, on les avait neufs, moi je faisais la couverture et je consultais déjà en travaillant, c'est comme ça, hein. ’

\subsubsection{Une docilité à l'égard de l'institution}

La curiosité du public de la liseuse est associée à une docilité culturelle et une déférence à l'institution qui conduit à une adhésion à ce qu'elle propose parce qu'elle le propose. Paradoxalement, la lecture numérique a été décriée in statu nascendi, car elle pourrait conduire à la disparition du livre papier, voire à la disparition des bibliothèques. L'idée d'un « numérique » qui pourrait se substituer au papier pèse fortement chez ce public qui emprunte pourtant la liseuse. Dans les entretiens comme dans les commentaires laissés après l'emprunt, ne pas souhaiter se détourner du livre papier est une revendication affirmée : " ne remplacera pas le livre papier », écrit un retraité. Toutefois, la liseuse prêtée par la bibliothèque constitue une forme de réification de l'institution. L'emprunter, c'est manifester son adhésion au service et à une démarche appréciée quel que soit le jugement porté sur l'expérience : « remerciement à tous les responsables qui mettent un équipement nouveau et de qualité à disposition des lecteurs » (homme, cadre, 50-60 ans). books from independent bookshops. What is more, she does not usually keep her books, but gives them back to the organizations. She carries a legitimist judgement of her practices and rejects "commercial" culture - thus arguably displaying solidarity with the book trade: "I shouldn't say this, but I discovered that Leclerc have a very, very big bookshop, which is really interesting, and easy to access... Well, since it's not an independent bookshop..." She distances herself from certain goods and values others: "I used to read soppy novels when I was a teenager, I can't remember what. I read thrillers when I worked at the library and, with some of the librarians - we had new copies - I made the cover and of course I had a look at it while I worked."

\subsubsection{Acquiescence Towards the Institution}

The curiosity of the e-reader audience goes hand in hand with a cultural acquiescence and institutional deference which leads to adhering to what is offered simply because it is on offer. Paradoxically, digital reading was condemned in statu nascendi, since it could lead to the disappearance of paper books, or even the disappearance of libraries. The notion of a digital replacement for paper weighs heavily on the readers, who still borrow e-readers. In interviews and written comments, many insist on not wanting to turn their back on paper books: "[They] will not replace paper books", writes one retired man. Nevertheless, the e-readers on loan at the library constitute a kind of commodification of the institution. Borrowing one means manifesting one's adherence to the service and to a procedure which is appreciated, regardless of the judgement of that experience: "Many thanks to those responsible for putting new and quality equipment at the readers' disposal" (executive male, 50-60 years old). 
Cette adhésion va de pair avec une satisfaction plus générale exprimée à l'égard d'une institution qui s'est rendue plus accessible, géographiquement et socialement, à l'instar de ce qu'explique Mme T. : « On n'allait pas en bibliothèque parce qu'en ce temps-là... Bon, moi, je viens d'une famille pauvre. Comme beaucoup de gens, on n'allait pas en bibliothèque. C'est après [...] je pense que les enfants, on les a amenés, par les écoles, ils ont été en bibliothèque. " Elle ajoute avoir commencé à fréquenter la bibliothèque lorsqu'elle travaillait à l'usine : "C'était la bibliothèque comme vous avez pas connu, vous savez, une bibliothèque à l'ancienne où tous les livres étaient reliés de la même couleur, avec une couverture de la même couleur, la bibliothécaire avec sa blouse grise et qui surveillait pour voir si on n'allait pas voler un livre (rire). " Dans cette optique, s'intéresser à la liseuse électronique proposée en bibliothèque, c'est affirmer et perpétuer l'institution, parfois de manière pleinement consciente. M. S., 29 ans, étudiant en master, explique : "Si on n'utilise pas ce que la bibliothèque

propose, alors la bibliothèque n'aura plus de raisons d'être. ”

\subsection{Effet générationnel et recherche de distinction par la compétence numérique}

Un effet générationnel et la construction d'une distinction par la compétence numérique se combinent à la bonne volonté culturelle de ce public pour permettre de comprendre ce qui se joue dans l'emprunt de la liseuse à la bibliothèque. Des logiques d'intégration sociale ou professionnelle sont sous-jacentes à cette démarche.

1.2.1. Pour les plus âgé·e·s, acquérir des compétences numériques

L'approche en termes de classe sociale est insuffisante pour comprendre ce qui se joue dans l'emprunt de la liseuse pour ces usager-ère·s, en particulier pour la majorité d'entre eux/elles
This compliance goes hand in hand with a more general satisfaction expressed regarding an institution which has made itself more geographically and socially accessible, as Mrs T. explains: "We didn't go to the library because back then... Well, I come from a poor family. Like many people. We didn't go to libraries. It was afterwards [...] I think it was the children, we brought them, they started going to libraries through school." She added that she started attending libraries when she started work at the factory: "It was a library the likes of which you have never seen, you know, an old-school library where all the books were bound in the same colour, the librarian with her grey blouse who watched to make sure we didn't steal any books [laughs]." In this light, showing interest in the e-readers on offer at the library means giving one's support to the institution, sometimes in a fully conscious manner. Mr S, a 29-year-old master's student, explains: "If we don't use what the library has to offer, the library will no longer have a purpose."

\subsection{The Generational Effect and the Search for Differentiation Through Digital Skills}

The generational effect and differentiating by ways of digital skills, along with the audience's cultural goodwill allow us to understand what is at stake when borrowing e-readers from the library. Social or professional interaction logics underpin the procedure.

\subsubsection{Older People and Acquiring Digital Skills}

Approaching the analysis in social class terms is insufficient in terms of understanding what is at stake when these users borrow e-readers, especially for the majority who are over fifty. 
âgée de 50 ans et plus. La surreprésentation des 50-59 ans invite en effet à envisager une approche générationnelle. Pour ces usager ère's issu·e's d'une génération qui " au moment où internet et ordinateurs entrent dans leur foyer et dans leurs pratiques, constituaient une part de la population déjà ou encore active et dont les enfants étaient encore à la charge du foyer " (Kellner 2017a), la transmission de compétences numériques s'est faite en partie dans la famille et l'univers professionnel et se poursuit en bibliothèque. Dans une logique d'ascension sociale et de déférence à la culture, l'emprunt de la liseuse met en jeu l'acquisition ou le renforcement de compétences numériques qui traduisent une recherche de distinction culturelle par la maîtrise des outils numériques. La liseuse électronique empruntée à la bibliothèque constitue une possible forme objectivée du capital culturel qui fait appel à des compétences techniques (savoir utiliser l'outil et ses différentes fonctionnalités), ainsi qu'à la capacité à se repérer dans l'offre des biens culturels numériques en ligne (savoir utiliser le web, chercher des livres numériques, connaître et se repérer parmi les plateformes de vente en ligne), et la maîtrise d'un lexique propre à l'univers numérique (comprendre et être capable de parler du « numérique »).

La maîtrise de ces compétences est un principe de différenciation. Certain'e.s expriment un sentiment d'exclusion vis-à-vis des générations plus jeunes. Le «numérique » leur semble remettre en cause leur ascension sociale et l'investissement scolaire et culturel qui l'a permise. Dès lors, les médiations proposées par la bibliothèque, que ce soit par la mise en prêt de la liseuse avec explications du ou de la bibliothécaire, mode d'emploi de l'appareil réécrit et simplifié, ou ateliers plus approfondis, sont investies comme un moyen de compenser les inégalités découlant d'un accès différencié du point de vue générationnel aux objets et

contenus numériques.
The overrepresentation of 50-59 year olds indeed invites us to consider a generational approach. For the users from a generation which "constituted a portion of the population which was still or already active, and whose children were still dependent on the household, when computers and the internet entered their homes and practices" (Kellner 2017a), the transmission of digital skills happened in part within the family and the professional world and continued in libraries. In an upward mobility and cultural deference logic, borrowing e-readers puts the acquisition or strengthening of digital skills at stake, which indicate a search for cultural distinction through the mastery of digital devices. Borrowing electronic readers from the library constitutes a possible objectified form of cultural capital which calls upon technical skills (knowing how to use the device and its different functions), as well as the capacity to navigate available online cultural goods (knowing how to use the web, searching for digital books, knowing and being able to navigate online sales platforms), and the mastery of a lexicon that is specific to the digital world (knowing and being able to speak "digital").

Mastering these skills is a principle of differentiation. Some borrowers claim to feel excluded by younger generations. The digital world seems to put their social ascent into question, along with the scholarly and cultural investment that permitted it. Subsequently, mediation services offered by the library - whether through lending e-readers with explanations from the librarian, a re-written and simplified user manual for the device, or in-depth workshops-are invested in to bridge the inequalities that result from differentiated access to digital devices and content from a generational perspective. 
Mme E., 71 ans, retraitée de l'enseignement primaire, est née dans le $5^{\mathrm{e}}$ arrondissement de Paris dans une famille appartenant aux classes populaires. Mariée à un informaticien à la retraite qui n'est plus en mesure de l'aider pour des raisons de santé, elle sollicite son fils sur les questions numériques. Elle fréquente théâtre et cinéma d'art et d'essai, lit parfois la presse locale, feuillète des magazines féminins, et ses lectures se tournent vers la « philosophie » et les questions d'actualité - elle affectionne particulièrement Alain Finkielkraut. Elle fréquente régulièrement la bibliothèque, ses ateliers multimédias, et déclare plusieurs fois au cours de l'entretien se sentir « vieille » et « nulle » pour ce qui concerne les nouvelles technologies : " y'a quand même un rapport à la machine, où, là, je me sens très très vieille ». " Non seulement je n'avais jamais manipulé de liseuse, mais en plus je n'ai même pas un portable comme vous [smartphone], j'ai un portable à l'ancienne où on ne fait même pas de SMS, rien du tout, alors vous voyez un peu ce que j'ai. [...] Mais je n'en suis même pas à la tablette encore, ni au portable iPhone, ni rien du tout Alors, je suis nulle nulle nulle, je n'ai que l'écran et les mails : c'est tout ce que je sais faire. " Exprimant un sentiment d'exclusion lié à une incompétence dans l'utilisation des objets numériques, cet extrait souligne que l'enjeu de cet emprunt pour elle n'est pas tant la lecture que l'acquisition d'une compétence numérique visible et socialement reconnue constituant un marqueur d'intégration sociale. Si l'effet générationnel négatif peut supposément être compensé par le recours à la médiation en bibliothèque, c'est parce que leur bonne volonté culturelle l'y autorise.
Mrs E., a 71-year-old retired primary school teacher, was born into a working-class family in the fifth arrondissement of Paris. Married to a retired computer scientist who for health reasons could not continue helping her, she asked her son to help her with digital issues. She goes to the theatre and art-house cinemas, sometimes reads the local press and browses women's magazines. Her reading is geared towards 'philosophy' and current affairs - she particularly likes Alain Finkielkraut. She attends the library regularly, as well as its multimedia workshops, and during the interview she often stated that she felt "old" and "useless" when it came to new technology: "There's this whole relationship with devices, and that makes me feel very old." "Not only had I never used an e-reader, but I haven't even got one of those phones like you have [smartphone], I have an old-school mobile phone that can't even write text messages, nothing at all, so you can kind of see where I'm at.... But I haven't even got a tablet, iPhone or anything like that. So, I'm totally useless, I just have a screen and emails, that's all I can do." Illustrating a feeling of exclusion linked to her incompetence when using digital devices, this extract highlights that the act of reading was not at stake when she borrowed an e-reader, but instead the acquisition of visible and socially recognized digital skills which constitute a marker for social integration. If the negative generational effect can presumably be compensated by a resort to mediation in libraries, it is because cultural goodwill allows for this. 
1.2.2. Pour les bibliothécaires, mise en scène de soi et construction d'une identité professionnelle par les compétences numériques

L'acquisition de compétences numériques est également un enjeu pour la catégorie spécifique d'emprunteur.se.s que constituent les bibliothécaires eux/elles-mêmes. L'observation des ateliers de médiation numérique a permis d'y constater leur présence. Bibliothécaires en poste dans d'autres établissements, en recherche de poste ou préparant le concours seul·e·s ou dans le cadre d'une formation universitaire, ils/elles (et plus souvent elles) viennent pour observer l'atelier, prendre connaissance de l'offre, échanger avec les (futur·e.s) collègues. Se jouent alors autant l'acquisition de compétences numériques transférables dans l'univers professionnel que l'accès même à la profession, la construction d'une identité professionnelle et un renforcement du capital social au sein de cet espace professionnel. Mme B., bibliothécaire depuis sa reconversion professionnelle, fréquente plusieurs bibliothèques du département, et y emprunte des documents. Forte lectrice (un roman par semaine environ), elle s'est intéressée à la liseuse dans l'optique de la préparation au concours de bibliothécaire : « Je voulais avoir manipulé une liseuse si jamais j'avais une question

à l'oral. »

L'expérience de la liseuse est aussi, comme la lecture, une expérience subjective susceptible d'être partagée avec des membres de la famille, des ami·e.s et/ou collègues. Elle constitue, dans un contexte d'interaction sociale, une possibilité de mise en scène de soi (Goffman 1973) et de construction ou d'affirmation d'une appartenance à un groupe professionnel. Mme G., 31 ans, occupe un poste de bibliothécaire assistante spécialisée (BIBAS) ${ }^{13}$

13. Les BIBAS sont des agents de catégorie $B$ de la fonction publique, dont le statut est encadré par le décret $n^{\circ} 2011-1140$ du 21 septembre 2011 qui
1.2.2. Staged Presentation of Self and Professional Identity Building Through Digital Skills for Librarians

Acquiring digital skills is also an issue for librarians themselves, who constitute another specific category of borrower. Their presence was confirmed during observations of digital mediation workshops. Librarians who work at other institutions, looking for a job or preparing for professional exams alone or within a university training course, come to observe the workshop, take note of what is on offer, or to talk to future colleagues. Much is at stake here: acquiring digital skills that are transferable to the professional sphere as well as actual access to the profession, the construction of a professional identity, and the strengthening of social capital within this professional space. Mrs B., a librarian since having retrained, attends various libraries in the region and borrows documents from them. She is an avid reader (approximately a novel a week) and is interested in using the e-reader to prepare for the librarian exam: "I wanted to have handled an e-reader in case I was asked about it during the oral exam."

Just like reading, e-reading experiences are subjective and susceptible to being shared with family members, friends and/ or colleagues. In a social interaction context, it constitutes a possibility for a staged presentation of self (Goffman 1959) and to construct or affirm the idea of belonging to a professional group. Mrs G., 31 years old, has a job as a contractual specialized library assistant $(\mathrm{BIBAS})^{13}$ at a university library, and at the time of the

13. Specialized library assistants are category B public service agents, whose status has been guaranteed by the 21 September 2011 decree $n^{\circ} 2011-1140$, 
contractuelle en bibliothèque universitaire, et prépare, au moment de l'entretien, le concours de BIBAS afin d'être titularisée. Elle raconte le moment qui a suivi son emprunt de la liseuse :

" Alors, quand j'ai pris la liseuse, c'était un samedi, je m'en souviens parce qu'après j'ai retrouvé en fait une collègue au café et j'ai allumé la liseuse avec elle, et donc, bon, j'ai présenté un peu. Bon, c'était quand même une discussion parce qu'enfin y'avait plusieurs personnes. Ils disaient : «oui, mais quand même le papier, c'est toujours mieux, moi je crois pas trop, ça me plaît pas vraiment». Y'avait des profs, y'avait des bibliothécaires, voilà. Ben moi pour l'instant, je donne pas mon avis parce que j'ai pas testé. Après, je pense qu'il faut connaître et voir, et comparer. Et voilà, j'ai montré tout de suite à cette collègue. Après, j'ai montré un peu à mon ami qui est également bibliothécaire. Lui, il était moins intéressé, il a jamais testé. Donc bon, la liseuse était à la maison sur la table. Bon, ça l'intéressait pas plus que ça. »

Forte lectrice, principalement de littérature jeunesse et de livres documentaires, Mme G., 31 ans, n'avait jamais manipulé ni liseuse ni tablette numérique jusqu'alors, et se présente comme n'étant « pas trop, on va dire, high tech ». Si elle sourit en confiant que Zola n'est pas pour elle, elle exprime une division du monde dans laquelle elle se situe plutôt du côté des lettres que de la technique. Elle fréquente plusieurs bibliothèques du département où elle emprunte surtout des livres et des CD, parfois des DVD. Elle fréquente foires et salons du livre, et a emprunté deux fois

précise que leur sont confiées des tâches dans le domaine du traitement et de la conservation des collections, d'accueil du public, et d'encadrement des personnels en charge du magasinage. Le poste est accessible par voie de concours de la fonction publique aux titulaires d'un diplôme de niveau IV, mais peut aussi être occupé par des contractuel·le.s. interview was preparing for the BIBAS exam in order to get tenure. She recounted the time she borrowed an e-reader:

"So, when I borrowed the e-reader, it was a Saturday, I can remember that because after that I met up with a colleague at a cafe and I switched the e-reader on with her, and I showed it to her a bit. Well, it ended up being quite a discussion because there were lots of people around. They were saying: 'Yes, well, paper is always better in the end, I don't really believe in it, I don't really like it'. There were teachers there, and librarians too. I didn't say anything at first, I didn't give my opinion because I hadn't tested it out yet. In the end, I think you have to try it out and see, compare. So, I showed it to this colleague immediately. Afterwards, I showed it to my boyfriend who is also a librarian. He was less interested, he never tried it out. The e-reader was at home on the table, but he wasn't interested."

Mrs G., 31 years old, is a keen reader. She mainly reads children's literature and documentary books. She had never handled an e-reader or a digital tablet before, and described herself as "not very high-tech, let's say." Although smiled as she revealed that Zola was not really her thing, she expressed a view of a divided world in which she places herself on the literary rather than the technological side. She visits various libraries in the region where she mainly borrows books and CDs, sometimes DVDs. She attends book fairs and shows and has borrowed an e-reader twice after having discovered it during a presentation by the library at a book

in which it is stated that they are entrusted with tasks in the area of data processing and conservation, greeting the public and managing personnel in charge of stock. The job is accessible through public office exams for those with a level IV diploma but can also be held by contractual workers. 
la liseuse après l'avoir découverte lors d'une présentation par la bibliothèque sur le stand d'un salon. Sa motivation est au départ professionnelle : " je voulais savoir comment ça fonctionne la liseuse. II faut connaître les appareils. Après, si on veut proposer aux usager-ère·s, il faut bien connaître d'abord. "

L'emprunt de la liseuse a été l'occasion de plusieurs échanges avec des bibliothécaires en poste, érigés en modèle par cette enquêtée préparant le concours qui reprend à son compte leur discours : la bibliothèque est, à ses yeux, comme elle doit être : "polyvalente », " chaque petit morceau a sa place dans le panier » et la liseuse, " c'est positif », c'est une manière de donner « accès [à la lecture] au grand public [...] II faut évoluer, voilà, pour attirer plus de public, et toucher le plus qu'on peut, voilà ». Ces mots s'inscrivent d'une part dans la doxa professionnelle selon laquelle les bibliothèques françaises doivent évoluer et rattraper un certain retard (Bertrand $2006: 134)^{14}$ - le « numérique » en constitue un moyen - et d'autre part, dans la continuité d'un discours politique qui considère que le « numérique » donne un plus large accès à la culture et à la

lecture.

\section{De l'enchantement aux limites de la liseuse électronique en bibliothèque}

\subsection{Un enchantement sans lendemain}

L'appréciation de la liseuse tient d'abord d'un attrait pour la nouveauté, l'appareil ouvrant de nouveaux possibles, en termes d'horizons de lecture, mais aussi de possibilités techniques.

14. L'autrice revient, dans une perspective sociohistorique, sur ce qu'elle appelle la « rhétorique du retard » dans les discours institutionnels et professionnels et précise : « Ainsi, la rhétorique du retard conserve une certaine vitalité, toujours dans l'optique de légitimer les efforts attendus. Quelle que soit la situation objective, factuelle, statistique, on est toujours le retardataire de quelqu'un ». fair stand. Her motivation was professional at first: "I wanted to know how an e-reader works. You have to know how to use these devices. If we want to offer them to users later, we have to know them well first."

The topic of borrowing e-readers came up in many conversations with. Librarians are seen as models by a participant who was preparing her exam and used the same rhetoric: libraries, in her opinion, are as they should be: "versatile," "each little piece has its place in the basket" and as for the e-reader: "it's positive," it's a way to ensure "access [to reading] to the general public... We have to evolve, really, to attract a wider audience, and to reach out to as many people as possible." These words are inscribed, on the one hand, in the professional doxa, according to which French libraries need to evolve and catch up on a certain lag (Bertrand 2006: 134) ${ }^{14}$. Digital services thus constitute a means to do so and, on the other hand, in the continuity of a political discourse that considers that digital services grant wider access to culture and reading.

\section{The Charms and the Limits of E-readers in Libraries}

\subsection{Charm with No Future}

The appreciation of e-readers firstly concerns their innovation as they open up new opportunities in terms of reading horizons as well as technical possibilities.

14. The author refers, from a sociohistorical perspective, to what she calls the "lateness rhetoric" in institutional and professional discourse, and specifies: "Thus, the lateness rhetoric keeps a certain vitality, always with the aim of legitimizing expected efforts. Whatever the objective, factual, statistical situation, we are always someone's latecomer." 
2.1.1. L'enchantement pour la nouveauté comme un espace de possibles

Tournés vers la nouveauté, les emprunteur.se.s de liseuses décrivent l'appareil comme une fascinante ouverture de possibles résultant de deux de ses caractéristiques principales : la capacité d'y stocker des centaines de livres et la possibilité grâce à son caractère mobile et léger de les lire au moment et dans le lieu voulus (en marchant, quand il fait nuit noire, quand il y a du vent, etc.). M. R., 66 ans, retraité, indique en désignant la liseuse : « Là, il y a quatre cents livres dans une petite boîte. " Utilisées par de grandes enseignes comme arguments de vente et reprenant le mythe babélien évoqué par Jorge Luis Borges en 1941 dans sa nouvelle La Bibliothèque de Babel et par d'autres auteurs comme Umberto Eco dans Le Nom de la rose (1982), ces capacités de stockage renvoient au fantasme de posséder une bibliothèque infinie offrant un accès sans contraintes (sociales) à la lecture. La dématérialisation du livre et les possibilités techniques du support apparaissent ainsi comme une libération de la pratique de la lecture vis-à-vis des contraintes de volume et de poids induites par la matérialité du papier, obligeant à des choix d'objets, de temps

et d'espace.

L'enchantement pour la liseuse proposée par la bibliothèque résulte de la rencontre entre des dispositions d'usager-ère-s et la mise en scène de l'offre par des professionnel-le·s sur un temps donné où tous consentent à cet enchantement. Yves Winkin développe la notion d'enchantement à partir d'une formule de Samuel Taylor Coleridge, « willing suspension of disbelief » (suspension volontaire d'incrédulité) : « suspendre temporairement son incrédulité n'est pas exactement la même chose que s'investir dans une crédulité nouvelle ", mais suppose que tous les participants « jouent le jeu » (Lallement \& Winkin 2015 : 118)

\subsubsection{The Charm of Novelty as a Space of Possibilities}

Drawn to the novelty of e-readers, borrowers describe the device as a fascinating opening up of possibilities due to two of its main characteristics: its capacity to store hundreds of books and-its mobile and lightweight nature-the possibility of reading them any time, anywhere (while walking, in pitch dark, when it is windy, etc.). Mr R., 65 years old and retired, pointed to the e-reader, saying: "There are four hundred books in there, in this little box." Used by big brands as selling points and, taking up the Babelian myth evoked by Jorge Luis Borges in his 1941 short story The Library of Babel and by other writers such as Umberto Eco in The Name of the Rose (1982), these storage capacities hark back to the fantasy of possessing an infinite library, offering (socially) limitless access to reading. The dematerialization of books and the device's technical possibilities thus appear as a liberation of reading practices compared with the size and weight constraints tied up with the materiality of paper which force us into selecting objects and defining time and space.

The attraction of e-readers on offer in the library results from the encounter between user dispositions and the offer presented by professionals over a given time, in which all parties accept this attraction. Yves Winkin developed the idea of charm from a formula by Samuel Taylor Coleridge, "willing suspension of disbelief": "temporarily suspending one's disbelief is not quite the same as investing in a new belief" but supposes that all participants "play along" (Lallement \& Winkin 2015: 118). 
L'adhésion n'implique d'ailleurs pas nécessairement l'usage : les usager-ère's admettent ne pas toujours exploiter les possibles qu'ils ou elles vantent. M. S., 63 ans, retraité, n'a pas transporté la liseuse, mais considère que " dans des endroits un peu hétéroclites comme un camping ou un truc de ce goût-là où la liseuse, ça permet d'en emporter plusieurs, et c'est un tout petit volume, c'est là l'avantage ". Sans être naïf, l'enchantement pour la liseuse comme bibliothèque infinie s'accompagne d'une forme de dénégation temporaire que Winkin explique par une formule empruntée à Octave Mannoni : « Je sais bien, mais quand même »

(Mannoni 1969)

L'enchantement n'existe que grâce au travail des professionnel·le·s de la bibliothèque, qui, en "ingénieur.e.s de l'enchantement », mettent en œuvre, en coulisse, l'ingénierie nécessaire à la production de la croyance : valorisation des outils et contenus numériques via des dispositifs de médiation et un plan de communication - recensement dans l'agenda de la bibliothèque, affichages, organisation d'autres manifestations autour du " numérique » (conférences, expositions), injonction à communiquer sur ces dispositifs. Les bibliothécaires jouent le jeu avec plus ou moins de conviction selon leur représentation du métier. In fine, l'enchantement repose sur une rencontre d'affinités électives, entre un public que ses dispositions portent à jouer le jeu et des professionnel-le.s qui se retrouvent dans des valeurs de nouveauté, et « qui s'aident mutuellement dans les opérations de dénégation et de suspension » (Winkin 2015 : 118).

2.1.2. Des éléments techniques comme justification

Outre l'émancipation des contraintes d'espace et de temps associée à la liseuse, ce sont les qualités techniques de celleci qui sont mises en avant par les emprunteur.se-s pour justifier
Moreover, compliance does not necessarily imply use: users admitted to not always exploiting the possibilities they boasted of. Mr S., 63 years old and retired, did not carry his e-reader around, but was of the opinion that "[it's useful] in places that are a bit heterogenous, like campsites or something like that, where you can have many [books] with you, and the advantage is that it's very small." Without being naive, the e-reader's charm as an infinite library goes hand in hand with a kind of temporary denial that Winkin explains with the help of a quotation by Octave Mannoni: "I know well, but all the same" (Mannoni 1969).

Its charm only exists thanks to the work of library professionals, "charm engineers" who carry out the necessary engineering backstage to ensure that faith in these devices prevails. They do so by valuing tools and digital content through mediation devices and a communication plan-library agenda keeping, posters, organization of other events around "digital" services (conferences, exhibitions, etc.), all of which require communication. Librarians play along with varying degrees of conviction, depending on their professional profile. In fine, the charm hinges on an encounter with elective affinities, between an audience which plays along and professionals who come together around the value of novelty and who "help each other out in dealing with denial and suspension" (Winkin 2015: 118).

\subsubsection{Technical Elements as Justification}

Besides the emancipation from space and time constraints associated with the e-reader, its technical qualities are put forward by borrowers in order to justify their interest in it. It is seen as a 
l'intérêt qu'ils/elles lui portent. La liseuse est vue comme un « bon appareil » de lecture dont les performances, à savoir le confort de lecture, justifie l'utilisation. Marie Doga et Olivier Zerbib avaient déjà mis en évidence cette justification de la lecture numérique par des appréciations techniques à partir d'une enquête menée en 2014 sur une plateforme de livres numériques intégrée au dispositif $\mathrm{PNB}^{15}$ (Doga \& Zerbib 2016) : le livre numérique apparaissait plus pratique pour la lecture car manipulable, transformable et dynamique. Pour les emprunteur.se's de liseuses, ces éléments de justification technique se structurent autour de trois axes: l'empêchement physique, la mobilité géographique, et l'intégration de la lecture à d'autres tâches simultanées et liées. Ces intérêts se retrouvent plus ou moins à l'identique pour les livres audio. Un sondage réalisé pour le Syndicat national de l'édition (2017) estime à $18 \%$ la part des Français·es déclarant avoir déjà lu un livre audio, les trois principaux éléments qui en motivent la lecture sont le fait de faire autre chose en même temps (45\%), lire en situation de mobilité $(40 \%)$ et se reposer les yeux des écrans (35\%).

L'empêchement physique majeur qui suscite un intérêt pour la liseuse est constitué par des troubles de la vue. L'absence de rétroéclairage de l'appareil proposé à l'expérimentation et le grossissement des caractères sont deux fonctionnalités très commentées par les lecteur.rice-s qui attendent de ce type d'appareil un gain en termes de confort de lecture par rapport au livre papier. La technologie e-ink est moins souvent mentionnée en ces termes précis, mais les usager·ère-s constatent une différence de confort entre l'écran d'une tablette numérique ou d'un ordinateur et celui de la liseuse électronique. Au confort de lecture s'ajoute

15. Le PNB est un dispositif interprofessionnel incluant bibliothécaires, éditeur.rice-s et libraires, et sociétés informatiques. II a été lancé en 2014 sous l'égide du ministère de la Culture, afin de favoriser la diffusion d'une offre de lecture numérique par les bibliothèques publiques. "good device" for reading, and its ease while reading justifies its use. Marie Doga and Olivier Zerbib identified this justification of digital reading through technical evaluation via a survey carried out in 2014 on a digital book platform that was integrated into the PNB apparatus ${ }^{15}$ (Doga \& Zerbib 2016): digital books appeared to be more practical for reading because they were more dynamic, easily handled and convertible. For e-reader borrowers, these technical elements of justification are structured around three themes: physical hindrance; geographic mobility; and the integration of reading with other simultaneous and linked tasks. These advantages are more or less the same for audiobooks. A survey carried out by the National Editing Union (2017) estimated the number of French people who had listened to an audiobook at $18 \%$. The three main factors which motivate people to listen to audiobooks are being able to do something else simultaneously $(45 \%)$, reading while travelling (40\%), and eye strain relief from screens (35\%).

The major physical impediment which has led to an interest in e-readers was eyesight impairments. The absence of backlighting on the device and the character magnification tool were two functions that were particularly mentioned by readers, who expect this type of device to be easier to read than paper books. E-ink technology is less often mentioned in such terms, but users do notice a difference in comfort between the screen of a digital pad or computer and that of an e-reader. Not only are they comfortable to read, e-readers are also transportable. Readers who move around a lot and are used to doing so with one or more books use

15. Prêt numérique en bibliothèque [digital lending in libraries] is an interprofessional initiative which includes librarians, publishers, booksellers, and IT companies. It was launched in 2014 under the Ministry of Culture to encourage the availability of digital reading in public libraries. 
la mobilité. Le/la lecteur.rice qui se déplace et a l'habitude de le faire avec un ou des livres justifie par cet aspect son intérêt pour la liseuse. Emmanuel Pedler et Olivier Zerbib avaient identifié cet aspect comme déterminant dans leur étude sur l'introduction des cédéroms en bibliothèque (Pedler \& Zerbib 2001) ${ }^{16}$ et suggéraient d'ailleurs de considérer la mobilité géographique comme une variable pertinente en sociologie de la culture. Ils soulignaient à cet égard que les circulations n'ont pas la même signification selon le lieu d'implantation de la bibliothèque (Paris, centre urbain, zone rurale, ville périphérique) et selon la direction des déplacements (de ville à ville, de village à ville). Ils observaient un effet significatif de la variable sur trois des quatre sites étudiés, portant à penser que le philonéisme est directement lié à la mobilité - ce qui constitue une hypothèse sérieuse pour comprendre la durabilité de l'usage de la liseuse.

L'appareil permet également de réaliser des activités périphériques à la lecture. Mme G., qui a aussi les trajets quotidiens les plus longs, s'approprie tout particulièrement les fonctions annexes de la liseuse en la chargeant de textes à traduire :

« J'ai donc téléchargé des textes, des contes, en polonais, et donc j'ai traduit, et en plus on peut faire des notes justement sur liseuse [...]. Après, j'ai même utilisé pour écrire des lettres et j'ai transféré sur ma boîte mail où j'ai corrigé les accents, voilà et j'ai pu envoyer donc voilà [...]. J'ai gagné du temps. [...] Mes courriers personnels, mes mails, j'ai tapé dans la liseuse voilà, et après j'ai transféré sur Gmail et je les ai envoyés. Donc ça m'a beaucoup aidée. »

La liseuse présente des intérêts proches du livre audio (intégré dans les collections des bibliothèques municipales qui représentent

16. L'enquête par questionnaire ne comprenait pas cette variable qui s'est révélée lors des entretiens semi-directifs. this aspect to justify their interest in e-readers. Emmanuel Pedler and Olivier Zerbib identified this aspect as a determining factor in their study on the introduction of CDs in libraries (Pedler \& Zerbib $2001)^{16}$ and suggested a consideration of geographic mobility as a pertinent variable in cultural sociology. In this regard, they highlighted that travel is not necessarily the same depending on the library's location (Paris, urban centres, rural zones, and the outskirts of cities) and the direction of commute (town to town, village to town). They observed a significant effect of the variable on three of the four sites under study, which leads us to believe that neophilia is directly linked to travel-a serious hypothesis for understanding the e-reader's durability.

The device also allows for activities which are peripheral to reading. $\mathrm{Mr} \mathrm{G}$., who has the longest commute, uses the e-reader's additional features and downloads texts to be translated:

"I downloaded texts, tales, in Polish, and translated them, and I can even take notes on the e-reader [...]. I even used it to write letters that I transferred onto my email to correct accents, and I was then able to send them [...]. I saved time. [...] I typed up my personal letters and emails onto the e-reader, and then transferred them to Gmail and sent them. So, it helped me out a lot."

E-readers present similar advantages to audiobooks (integrated into town library collections and representing an access point

16. The survey did not feature this variable which was revealed during the semidirective interviews. 
un point d'accès pour $25 \%$ de ses lecteur.rice.s) mais auss des potentialités spécifiques. Elle s'intègre d'autant mieux dans les habitudes de consommation culturelle que les possibilités techniques de l'appareil correspondent davantage au style de vie du/de la lecteur.rice et à sa position sociale.

\subsection{Offre littéraire classique, valeur symbolique du livre papier et compétences : des freins à la pratique de la lecture \\ sur liseuse}

En dépit des aspects positifs soulignés par les emprunteur.se's, ceux/celles-ci n'ont pas toujours lu sur la liseuse. Certain·e.s n'ont lu que des passages, incipit ou extraits. Rares sont ceux et celles qui ont lu un livre entier. D'autres enfin n'ont que « navigué » dans les menus. L'offre littéraire classique proposée sur la liseuse de la bibliothèque, la valeur symbolique restant attachée au livre papier et les compétences nécessaires à la maîtrise de l'appareil constituent autant de freins à la lecture sur liseuse. Au total, l'expérience se révèle rarement positive et, pour environ trois quart des interviewé·e.s, restera sans lendemain

\subsubsection{La littérature classique absente des profils culturels} des lecteur.rice.s

Un premier désajustement naît du décalage entre l'offre de contenus proposés sur la liseuse dans ce contexte d'expérimentation et les goûts littéraires des emprunteur.se.s. L'offre est en effet très restrictive au regard de ce que proposent les bibliothèques dans leurs collections. Comme le note Cécile Rabot, "si les classiques scolaires sont présents dans les fonds des bibliothèques de lecture publique ", ils ne constituent pas les ouvrages les plus mis en avant, soit qu'ils soient considérés comme trop bien connus soit qu'ils soient perçus comme des « productions à public restreint réputées difficiles donc moins susceptibles de procurer au plus for $25 \%$ of readers) as well as specific potential. They are well integrated into general cultural consumption habits, to the extent that the device's technical possibilities correspond to readers' lifestyles and social profiles better.

\subsection{The Availability of Classics, the Symbolic Value and Advantages of Paper Books: Obstacles to Reading Practices on E-readers}

Despite the positive aspects highlighted by borrowers, they did not always read on their e-readers. Some only read passages, openings, or extracts. Few read an entire book. Others merely "browsed" the menus. The classics offered on the library e-readers, the remaining symbolic value attached to paper books, and the skills necessary to fully master the device constituted obstacles to reading on e-readers. All in all, the experience rarely turned out to be positive, and for three-quarters of those interviewed, would be short-lived.

\subsubsection{Literary Classics Missing from the Readers' Cultural Profiles}

A first discrepancy stems from the mismatch between the content on offer in the e-readers in the context of this experiment and the literary tastes of its borrowers. The offer was indeed very restrictive compared with what the libraries offer in their collections. As Cécile Rabot notes, "Although school classics are available in public reading libraries," they are not the books that are most showcased, either because they are considered too well known, or because they are perceived as "famously difficult productions with a limited audience, thus less likely to procure reading pleasure to a wider 
grand nombre le plaisir de lire » (Rabot $2011: 89$ ). Les bibliothèques ont donc largement diversifié leurs fonds de manière à se rendre accessibles au plus grand nombre.

En 1988, Patrick Parmentier notait par ailleurs un recul des classiques parmi les genres lus en bibliothèque, qu'il associait à une crise de la légitimité culturelle (Parmentier 1988). La littérature classique constitue pourtant le troisième " genre » le plus cité parmi les genres lus par le public de la bibliothèque enquêté $e^{17}$ : elle $y$ est donc autant plébiscitée qu'au niveau national et figure avant plusieurs autres genres plus sollicités par les Français ${ }^{18}$. Mais les emprunteur.se.s de la liseuse ne la comptent pas au nombre de leurs préférences : les textes littéraires classiques ne s'intègrent pas à leurs habitudes de lecture ni en bibliothèque ni en dehors. La bonne volonté culturelle des classes moyennes n'exclut pas la mise à distance de produits culturels légitimes parfois rejetés, comme le note Bernard Lahire avec l'exemple de Nadège, comme trop « intello ", « snobs » (Lahire 2006). Surtout, les classiques demeurent associés à la prescription scolaire et à une littérature d'un autre temps : « peut-être plus de livres récents sur la liseuse » (homme, profession intermédiaire, 40-50 ans), " très bon choix de titres pour le $3^{\text {e }}$ âge et les maisons de retraite 》 (femme, employée, 40-50 ans). A cet égard, les emprunteur.se-s de liseuses rejoignent la distance à l'égard des classiques que manifestent les bibliothécaires en les mettant peu en avant sur les présentoirs. Ils/

17. $35 \%$ des usager·ère-s déclarent avoir lu des œuvres de la littérature classique au cours des douze derniers mois, ce qui place ce genre derrière les romans autres que policiers $(60 \%)$ et les romans policiers $(47 \%)$

18. Voir ici l'enquête menée par Ipsos pour le Centre national du livre " Les Francais et la lecture en 2017 ». Le sondage fait apparaître que, pour un taux sensiblement identique (34\%), la littérature classique ne fait pas partie des trois genres les plus lus par les français (p. 13). audience" (Rabot 2011: 89). Libraries thus diversified their content in order to become more accessible to a wider audience.

Furthermore, in 1988, Patrick Parmentier noted a decline in classics among genres read in libraries, which he linked to a cultural legitimacy crisis (Parmentier 1988). Yet classics constitute the third most cited "genre" among those read by the audience at the library in this study ${ }^{17}$. Classics are read just as much there as on the national level, and figure ahead of many of the other genres most requested by the French general public ${ }^{18}$. But e-reader borrowers do not count them among their preferences: classic texts are not part of their reading habits, whether inside libraries or outside. The middle classes' cultural goodwill does not exclude distancing legitimate cultural products that are sometimes rejected as too "intellectual" or "snobbish," as noted by Bernard Lahire with the Nadege example (Lahire 2004). Classics are still mainly associated with school requirements and literature from the past: "I guess I read more recent books on the e-reader" (40-50 year-old man, intermediary profession); "the e-books on offer are good choices for the elderly and retirement homes" (40-50 year-old woman, employee). In this regard, e-reader borrowers are just as distant towards classics as librarians, who seldom showcase them. Motivated by novelty, they thus share common values.

17. $35 \%$ of users declare having read classics in the last 12 months, which places this genre behind non-crime fiction $(60 \%)$ and crime fiction $(47 \%)$

18. See the survey carried out by Ipsos for the Centre national du livre, "Les Français et la lecture en 2017" [The French and reading in 2017]. The survey revealed that, for a seemingly identical rate $(43 \%)$, classics are not among the three most read genres by French people (p. 13). [Accessed on 25 July 2019.] 
elles témoignent ainsi des valeurs qu'ils/elles ont en commun avec eux/elles et qui les portent vers la nouveauté.

Dans les cas où l'expérience de l'emprunt de liseuse a conduit à la lecture d'un ouvrage entier, les emprunteur.se-s étaient surtout les lecteur.ice.s de classes moyennes au profil culturel consonant à tendance plutôt légitime. C'est le cas de Mme E. que son ancienne profession d'enseignante rend plus réceptive à l'offre littéraire classique. Elle déclare avoir lu un livre « que je n'avais jamais lu dans ma jeunesse, Le Grand Meaulnes, et n'aurais sans doute pas lu si je ne l'avais pas pris dans la liseuse [...] un livre que j'aurais dû lire quand j'avais 18 ans ou 16 ans [...]. J'étais enseignante, j'aurais dû l'avoir lu, mais enfin bon (rire) ».

\subsubsection{Le livre papier, une valeur symbolique supérieure}

La valeur symbolique du livre papier demeure très forte chez ces usager·ère-s tenté.e.s par la nouveauté. Elle est pour eux supérieure au numérique qui peine à se légitimer. Le livre papier constitue la référence à laquelle la liseuse est systématiquement rapportée. La lecture numérique sur liseuse mobilise les schémas durablement incorporés au cours des socialisations primaires et secondaires, associées au livre imprimé, qui ont précédé l'émergence du numérique et généré des manières de lire et de penser la lecture. De même que la pratique de la photographie dans les photo-clubs bourgeois gardait en ligne de mire la peinture et cherchait à s'en approprier la dignité (Castel \& Schnapper 1965 : 144-172), les lecteurs et lectrices se réfèrent au livre papier pour se distancier d'un support numérique qu'ils perçoivent comme moins digne.

C'est en faisant appel à des aspects sensoriels que beaucoup décrivent ce qu'ils ou elles considèrent comme un défaut du
In cases where borrowing an e-reader led to reading an entire book, the borrowers were mainly female middle-class readers, with a consonant cultural profile and a rather legitimate tendency. Such was the case of Mrs E., who was receptive to classics thanks to her former job as a teacher. She states having read a book "hat I never read when I was young, Le Grand Meaulnes, and I would have probably never read it if I hadn't had it on the e-reader... [it's] a book that I should have read when I was 18 or 16 years old... I was a teacher, I should have read it, oh well [laughs]."

\subsubsection{The Higher Symbolic Value of Paper Books}

The symbolic value of paper books remains very strong among those users drawn to the device's novelty. They are seen as superior to digital books, which have a hard time gaining legitimacy. Paper books constitute the reference that e-readers are systematically compared with. Digital reading on e-readers mobilized patterns incorporated over a long period of time during primary and secondary school socialization, associated with printed books, which preceded the emergence of digital devices and generated specific ways of reading and thinking about reading. Just like the practice of photographs in bourgeois photo-clubs kept painting in its line of sight and aimed at acquiring the same dignity (Castel \& Schnapper 1965: 144-172), readers refer to paper books to maintain a distance from digital media, which they perceive as less worthy.

Many describe what is lacking in digital books compared with paper books in sensory terms: e-readers "cannot replace a book: we like 
numérique par rapport au papier : la liseuse « ne remplace pas un livre : on aime toucher un livre, le caresser (s'il nous a plu), le plaisir de posséder un livre que l'on aime, envie de tourner les pages " (femme, autres données inconnues) ; "À une époque, mais c'est moins vrai aujourd'hui, j'aimais l'odeur du papier " (Mme M., 65 ans, psychologue retraitée). Le plaisir de la lecture apparaît intrinsèquement lié à l'engagement des sens et si le livre semble « parler au corps ", la lecture sur papier s'apparente à une pratique " par corps ${ }^{19}$, dont les gestes, incorporés, semblent plus naturels, quand la liseuse nécessite des essais, des recherches, et parfois une médiation. La déception de la lecture numérique pratiquée sur la liseuse mais pensée en référence à la lecture sur papier tient donc d'une lecture qui cherche à imiter la Lecture, à reproduire sur un support nouveau les gestes adaptés au papier ${ }^{20}$.

De fait, les emprunteur.se-s traitent la liseuse comme un livre papier, de son emprunt à sa restitution. Au domicile, ils/elles la déposent le plus souvent avec la pile des livres empruntés : « sur le bord de la table de nuit par exemple ou l'accoudoir du fauteuil [...] Et je l'ai considérée [la liseuse] tout à fait comme un livre »

19. L'expression « par corps » renvoie ici aux notions, employées par Pierre Bourdieu, d' "apprentissage par corps » $(1980: 123)$ et de " connaissance par corps » (1997 : 197), qu'il explorait déjà avec celle du " corps cultivé " des femmes bourgeoises (1979:443). Les pratiques «par corps » ne sont pas des actes intentionnels mais reflètent l'extériorisation de régularités incorporées devenues dispositions durables (1997: 197). Le " corps lecteur " exprime alors tout autant des schèmes de pensée que d'action incorporés et lire «par corps » sur la liseuse, c'est reproduire des régularités connues de la lecture papier sur l'appareil électronique. Aussi, Loïc Wacquant et Sylvia Faure précisent, dans le cas de la boxe (Wacquant 2002) et de la danse (Faure 2000), que ces régularités résultent d'un apprentissage, en montrant les mécanismes du processus d'incorporation de la pratique.

20. Annette Béguin faisait une observation analogue sur les lectures à l'écran : " le corps virtuel se projette dans le dispositif à l'écran avec les schèmes moteurs de la lecture de livre qu'il a déjà intégrés... » (Béguin 2001 : 149) touching a book, to stroke it (if we like it), the pleasure of owning a book that we like, the desire to turn pages" (woman, missing data); "Back in the day-though it's less true today-I liked the smell of paper" (Mrs M., 65 years old, retired psychologist). The pleasure of reading seems intrinsically linked to sensory engagement, and as books seem to "speak to the body," reading on paper is thus like a "bodily"19 practice, whose embodied gestures seem more natural than those of the e-reader, for which effort and practice, search, and sometimes mediation are necessary. The disappointment in digital reading on an e-reader compared with reading on paper comes from a reading process that wishes to imitate or even reproduce the gestures adapted to paper on a new medium ${ }^{20}$.

In fact, borrowers treat an e-reader like a paper book, from the moment they borrow it to when they return it. At home, they usually leave it on the pile of borrowed books: "On the bedside table for instance, or on the arm of a chair... And I considered it [the e-reader] just like a book." (Mrs E.) Though they may pay extra

19. The expression "bodily" refers here to Bourdieu's notions of "bodily learning" (1980: 123) and "bodily knowledge" (1997: 197), which he explored with the notion of the "cultivated/cultured body" of bourgeois women (1979: 443). "Bodily" practices are not intentional acts but reflect the exteriorization of incorporated regularities that become lasting dispositions (1997: 197) The "reading body" thus expresses patterns of thought as well as patterns of embodied action and reading an e-reader in a "bodily" manner means reproducing known regularities of paper reading onto the electronic device. Loïc Wacquant and Sylvia Faure add that, in the case of boxing (Wacquant 2002) and dance (Faure 2000), these regularities result from a learning process, showing the mechanisms of the practices' incorporation process.

20. Annette Béguin made a similar observation about reading on a screen: "the virtual body projects itself onto the on-screen device with the same movement patterns as book-reading that it has already incorporated..." (Béguin 2001: 149) 
$(\text { Mme E. })^{21}$. S'ils/elles lui accordent une attention particulière liée au coût qu'engagerait une détérioration, les lieux et les moments dédiés à la lecture sont ceux du livre papier. Les rituels sont reproduits dès les premiers instants : utilisation du marque-page, grossissement à la loupe, surlignage, prise de notes, utilisation du

dictionnaire..

2.2.3. De la bonne volonté, mais pas toujours les compétences

La référence au livre papier se combine à un usage plus ou moins maîtrisé de la liseuse pour faire obstacle à son utilisation. Les manières de penser et de faire avec le livre papier persistent mais ne sont plus adaptées, engendrant un sentiment d'incompétence. Mme E., venue en entretien avec sa propre liseuse, décrit ses difficultés comme des caprices de l'appareil refusant d'afficher le clavier : «Alors ce que je comprends pas, c'est pour avoir le clavier. De temps en temps il apparaît, mais quand je veux qu'il apparaisse, il apparaît pas. Oui, mais voyez, c'est très doux. Moi je crois que je suis pas du tout faite pour le numérique, je tape là-dessus comme si... vous voyez, je la défonce ! (rire) 》 J'appuie à sa demande sur l'icône pour faire apparaître le clavier : " Alors, vous voyez, vous, vous avez la main magique, voilà, vous avez la main-écran (rire). " Ainsi l'absence de compétence doublée de la persistance de schémas inadéquats ne permet pas une utilisation sereine de l'appareil et conduit souvent, in fine, à l'abandon. Au moment des entretiens, Mme E. est d'ailleurs la seule des enquêtées à persister dans l'utilisation de l'outil : déterminée à parvenir à manipuler la liseuse, elle l'a empruntée deux fois et a fini par posséder la sienne. attention to it because of the cost that any damage would entail, the places and moments dedicated to reading are the same as with paper books. The rituals are replicated from the very beginning: use of a bookmark, use of a magnifying glass, highlighting, note taking, dictionary use, etc.

\subsubsection{Goodwill, But Not Always Accompanied by the Necessary} Skills

The reference to paper books, combined with a more or less mastered use of the e-reader, interferes with its use. Modes of action and thought with paper books persist but are not adapted, which lead to a feeling of incompetence. Mrs E., who came to an interview with her own e-reader, puts her difficulties down to the whims of the device, which refused to display the keyboard: "What I don't understand is how to get to the keyboard. Sometimes it appears, but when I want it to appear, it doesn't. Yes, you see, it's very soft. I don't think I'm made for digital things; I bang on it as if... See, I'm smashing it! [laughs]". At her request, I press on the icon to make the keyboard appear: "See, you have the magic hand, that's it, you have a screen-hand [laughs]." Thus, the absence of skills along with the persistence of inadequate patterns does not allow for a serene use of the device and often leads to ultimately abandoning it. At the time of the interview, Mrs E. was nevertheless the only surveyed person who insisted on using the device: she was determined to succeed in handling the e-reader and borrowed it twice before buying her own.

21. Présentée précédemment dans la partie 1.2.1. 


\section{Conclusion}

En conclusion, comprendre la lecture numérique sur liseuse en bibliothèque municipale telle qu'elle s'offre au moment de l'enquête, suppose de s'efforcer d'articuler différents niveaux d'analyse. Questionner les raisons pour lesquelles les agents empruntent une liseuse, leur(s) intérêt(s) ou désintérêt pour la forme de lecture qu'elle suppose, c'est-à-dire une lecture technique qui fait appel à des connaissances et des compétences nouvelles et en même temps expérimentale, c'est révéler des mécanismes invisibles qui participent de la construction de leur choix et qui dépendent de leur propre vision de la lecture. Fort.e.s lecteur.rice.s, caractérisé.e.s par leur bonne volonté culturelle, ils/elles ne correspondent pas forcément au public ciblé par les politiques publiques de la lecture qui cherchent avec le "numérique " à élargir la lecture, mais constituent pourtant bien celui que ce dispositif expérimental

pouvait atteindre.

L'articulation des différents niveaux d'analyse devient intéressante pour comprendre que, plus que des destins individuels, ce qui s'exprime à travers cet emprunt et ces usages de la liseuse, c'est finalement une manière d'être lecteur.rice, de penser et de pratiquer la lecture. En somme, c'est l'expression d'un habitus de lecteur.rice qui s'est construit tout au long d'une trajectoire ascendante, habitus fortement marqué par l'incorporation de normes et de valeurs et par une déférence envers la culture et l'institution culturelle. La bonne volonté culturelle ne suffit toutefois pas souvent à rendre la pratique heureuse et donc à permettre son maintien, faute de compétences, qui renvoient moins à des dispositions de classe qu'à un effet générationnel. D'un attrait pour la nouveauté et d'une adhésion confiante à un service proposé par une institution culturelle reconnue, à l'abandon d'une pratique qui semble ne pas pouvoir procurer tout le plaisir de la lecture sur papier, l'enquête

\section{Conclusion}

To conclude, understanding digital reading on e-readers in town libraries as they were on offer at the time of the survey involves struggling to articulate various levels of analysis. By questioning the reasons individuals borrow an e-reader, their interest(s) or disinterest in the kind of reading it supposes-i.e., a technical type of reading which calls upon knowledge and skills and is also experimental - I revealed invisible mechanisms that participate in the construction of their choice and depend on their own vision of reading. As avid readers, characterized by their cultural goodwill, they do not necessarily correspond to the audience targeted by public reading policies that are trying to use digital means to widen reading, but nevertheless constitute the groups that this experimental device might hope to reach.

Articulating different levels of analysis becomes interesting when we understand that, more than individual stories, what is expressed through such uses of e-readers is a way of being a reader, of thinking and practising reading. In short, it is the expression of the reader's habitus that has constructed itself along an upward social trajectory, a habitus that is strongly impacted by the incorporation of values and by a deference towards culture and cultural institutions. However, when the necessary skills are lacking, cultural goodwill is not enough to make the practice enjoyable and thus allow for it to continue. This harks back to a generational effect more than class dispositions. From attraction to the novelty of the device and a trusting compliance with a service proposed by a recognized cultural institution, the survey shows the ambivalence of the middle classes that are at once acquiescent, curious, and charmed, but equally disappointed, convinced that e-readers are not for them. 
montre toute l'ambivalence de classes moyennes à la fois dociles, curieuses, enchantées mais aussi déçues, convaincues que la liseuse n'est pas pour elles. Cherchant à conquérir une technicité qui semble annihiler l'investissement culturel et scolaire consenti pour leur ascension et l'accès à leur position sociale, elles peinent le plus souvent à s'approprier l'outil, faute d'en acquérir un maniement aisé, et se retranchent dans l'affirmation d'une valeur symbolique du livre papier que le livre numérique n'atteindrait jamais. À la seule exception d'une enquêtée (Mme E.), qui, motivée par un projet de mobilité (une croisière), acquiert une liseuse, l'expérience de la lecture numérique ne conquiert donc pas celles et ceux qui l'ont tentée, sans pour autant qu'ils/elles excluent toute possibilité future de réitérer l'essai.

Stéphanie Kellne Université de Rouen Normandie - Dynamiques sociales contemporaines (Dysolab)

\section{Références bibliographiques}

BÉGUIN Annette (2001). « Le corps dans les lectures à l'écran ». Spirale. Revue de recherches en éducation, $28: 145-162$

BERTRAND Anne-Marie (2006). « L'éternel retard ". Bulletin des bibliothèques de France, numéro hors-série « Regards sur un demi-siècle. Cinquantenaire du Bulletin des bibliothèques de France » : 113-134

Borges Jorge Luis (1952) [1941]. « La bibliothèque de Babel ». Fictions. Traduit de l'espagnol par Roger Caillois, Nestor Ibarra, Paul Verdevoye. Paris, Gallimard.

BOURDIEU Pierre (1979). La Distinction : critique sociale du jugement Paris, Minuit.

BOURDIEU Pierre (1980). «La croyance et le corps ». In Le Sens pratique. Paris, Minuit : 111-134.
Struggling to conquer a technology that seems to annihilate the cultural and scholarly investment agreed upon for their upward mobility and access to their social position, they mostly had a hard time dealing with the device, for want of handling it with ease, and hid behind the affirmation of the symbolic value of paper books that digital books will never achieve. Except for one respondent (Mrs. E.), who acquired an e-reader in view of a travel project (a cruise), the experience of digital reading did not win over those who tried it out, although they do not exclude the possibility of trying it again in the future.

Stéphanie Kellner Université de Rouen Normandie - Dynamiques sociales contemporaines (Dysolab)

\section{References}

BÉGUIN Annette (2001). "Le corps dans les lectures à l'écran." Spirale. Revue de recherches en éducation, 28: 145-162.

Bertrand Anne-Marie (2006). « L'éternel retard 》. Bulletin des bibliothèques de France, numéro hors-série « Regards sur un demi-siècle. Cinquantenaire du Bulletin des bibliothèques de France » : 113-134.

Borges Jorge Luis (1962). "The library of Babel." Labyrinths: Selected Stories and Other Writings. English translation by James E. Irby. New York, New Directions.

Bourdieu Pierre (2013) [1979]. Distinction. A Social Critique of a Judgement of Taste. English translation by Richard Nice. London/ New York, Routledge.

Bourdieu Pierre (1990) [1980]. "Belief and the Body." In The Logic of Practice. English translation by Richard Nice. Stanford, Stanford University Press: 66-79. 
BouRdieu Pierre (1997). « La connaissance par corps ». In Méditations pascaliennes. Paris, Seuil : 187-234.

CASTEl Robert \& SChNAPPER Dominique (1965). « Ambition esthétique et aspirations sociales ». In BouRdiEu Pierre (dir.). Un art moyen. Essai sur les usages sociaux de la photographie. Paris, Minuit : 144-172.

Coulangeon Philippe (2011). Les Métamorphoses de la distinction. Inégalités culturelles dans la France d'aujourd'hui. Paris, Grasset.

DogA Marie \& ZeRBIB Olivier (2016). « Le livre numérique en bibliothèques, entre absences et attentions. Études des formes de rematérialisation d'offres réputées immatérielles ". Revue de l'Enssib, 4.

Eco Umberto (1982) [1980]. Le Nom de la rose. Traduit de l'italien par Jean-Noël Schifano. Paris, Grasset.

FAURE Sylvia (2000). Apprendre par corps. Socio-anthropologie des techniques de danse. Paris, La Dispute.

GoFFMAN Erving (1973) [1959]. La Mise en scène de la vie quotidienne. Tome 1, La présentation de soi. Traduit de l'anglais par Alain Accardo. Paris, Minuit.

KELLNER Stéphanie (2017a). « Le numérique en bibliothèque municipale. L'emprunt de la liseuse : de l'accès à la lecture au recours à la médiation ». In Fries-Paiola Cécile, Gothuey Julie, Kessler-Bilthauer Déborah, PANISSET Thierry, REINERT Estelle (dir). Étudier la culture aujourd'hui. Enjeux identitaires, numériques, artistiques et spatiaux d'un objet de recherche pluriel. Nancy, Presses universitaires de Lorraine.

KELLNER Stéphanie (2017b). « En attendant les digital natives. Les publics et pratiques du numérique en bibliothèque municipale saisis par des méthodes d'enquête traditionnelles ". In BARRABAND Mathilde, BeLlemarE Ariane, Grenier Mélanie (dir.). Publics de la culture : perspectives croisées sur la réception et la médiation : actes de colloque. Laboratoire de recherche sur les publics de la culture, Érudit.org. [Consulté le 17 juillet 2020.]
BOURDIEU Pierre (2000) [1997]. "Bodily Knowledge." Pascalian Meditations. English translation by Richard Nice. Stanford, Stanford University Press: 128-163.

CAstel Robert \& Schnapper Dominique (1990) [1965]. "Aesthetic Ambitions and Social Aspirations: The Camera Club as a Secondary Group". In Bourdieu Pierre (ed.). Photography. A Middle-brow Art. English translation by Shaun Whiteside. Cambridge, Polity Press: 103128.

Coulangeon Philippe (2011). Les Métamorphoses de la distinction. Inégalités culturelles dans la France d'aujourd'hui. Paris, Grasset.

DogA Marie \& ZERBIB Olivier (2016). "Le livre numérique en bibliothèques, entre absences et attentions. Études des formes de rematérialisation d'offres réputées immatérielles." Revue de l'Enssib, 4.

Eco Umberto (1983) [1980]. The Name of the Rose. English translation by William Weaver. Houghton Mifflin Hartcourt.

FAURE Sylvia (2000). Apprendre par corps. Socio-anthropologie des techniques de danse. Paris, La Dispute.

GofFMAN Erving (1959). The Presentation of Self in Everyday Life. University of Edinburgh Social Sciences Research Centre, Anchor Books.

KELLNER Stéphanie (2017a). "Le numérique en bibliothèque municipale. L'emprunt de la liseuse: de l'accès à la lecture au recours à la médiation." In Fries-Paiola Cécile, Gothuey Julie, Kessler-Bilthauer Déborah , PANISSET Thierry, ReINERT Estelle (eds.). Étudier la culture aujourd'hui. Enjeux identitaires, numériques, artistiques et spatiaux d'un objet de recherche pluriel. Nancy, Presses universitaires de Lorraine.

KELLNER Stéphanie (2017b). "En attendant les digital natives. Les publics et pratiques du numérique en bibliothèque municipale saisis par des méthodes d'enquête traditionnelles." In BarRaBAnd Mathilde, Bellemare Ariane, Grenier Mélanie (eds.). Publics de la culture: perspectives croisées sur la réception et la médiation: actes de colloque. Laboratoire de recherche sur les publics de la culture, Érudit. org. [Accessed on 17 July 2020.] 
LAHIRE Bernard (2004). «Profils culturels dissonants dans les classes moyennes ». In LAHIRE Bernard (dir.). La Culture des individus. Dissonances culturelles et distinction de soi. Paris, La Découverte : 294-358.

LALLEMENT Emmanuelle \& WinKIN Yves (2015). «Quand l'anthropologie des mondes contemporains remonte le moral de l'anthropologie de la communication ». Communiquer, $13: 107-122$.

MANNONI Octave (1969). « Je sais bien, mais quand même... ». In MANNONI Octave (dir.). Clefs pour l'imaginaire ou l'autre scène. Paris, Seuil : 9-33.

PARMENTIER Patrick (1988). « Lecteurs en tous genres ». In Poulain Martine (dir.). Pour une sociologie de la lecture, lectures et lecteurs dans la France contemporaine. Paris, Le Cercle de la librairie : 125-152.

PASSERON Jean-Claude (1982). «Images en bibliothèque, images de bibliothèque ». Bulletin des bibliothèques de France, 27 :69-83.

PASSERON Jean-Claude \& GRUMBACH Michel (1985). L'CEil à la page. Enquête sur les images et les bibliothèques. Paris, Bibliothèque publique d'information.

Pedler Emmanuel \& ZerbiB Olivier (2001). Les Nouvelles Technologies à l'épreuve des bibliothèques. Usages d'internet et des cédéroms. Paris, Bibliothèque publique d'information.

RABOt Cécile (2011). Le Choix des bibliothécaires ou la fabrication des valeurs littéraires en bibliothèque de lecture publique. Thèse de doctorat en littérature française et sociologie. Paris, Université Paris 3 Sorbonne Nouvelle.

Roselli Mariangela \& PerRenoud Marc (2010). Du lecteur à l'usager. Ethnographie d'une bibliothèque universitaire. Toulouse, Presses universitaires du Mirail.

WACQUANT Loïc (2002). Corps et âme. Carnets ethnographiques d'un apprenti boxeur. Paris, Agone.

ZERBIB Olivier (2014). « Le livre numérique, une offre documentaire en voie d'apparition. Interrogations, anticipations et innovations dans les bibliothèques publiques de l'Isère ». Études de communication, 43 : 9293.
LAHIRE Bernard (2004). "Profils culturels dissonants dans les classes moyennes." In LAHIRE Bernard (ed.). La Culture des individus. Dissonances culturelles et distinction de soi. Paris, La Découverte: 294-358.

LALLEMENT Emmanuelle \& WinKIN Yves (2015). "Quand l'anthropologie des mondes contemporains remonte le moral de l'anthropologie de la communication." Communiquer, 13: 107-122.

MANNONI Octave (1969). "Je sais bien, mais quand même..." In ManNON Octave (ed.). Clefs pour l'imaginaire ou l'autre scène. Paris, Seuil: 9-33.

PARMENTIER Patrick (1988). "Lecteurs en tous genres." In Poulain Martine (ed.). Pour une sociologie de la lecture, lectures et lecteurs dans la France contemporaine. Paris, Le Cercle de la librairie: 125-152.

PASSERON Jean-Claude (1982). "Images en bibliothèque, images de bibliothèque." Bulletin des bibliothèques de France, 27: 69-83.

PAsseron Jean-Claude \& GRUMBACH Michel (1985). L'CEil à la page. Enquête sur les images et les bibliothèques. Paris, Bibliothèque publique d'information.

Pedler Emmanuel \& Zerbib Olivier (2001). Les Nouvelles Technologies à l'épreuve des bibliothèques. Usages d'internet et des cédéroms. Paris, Bibliothèque publique d'information.

RABOt Cécile (2011). Le Choix des bibliothécaires ou la fabrication des valeurs littéraires en bibliothèque de lecture publique. PhD dissertation, French Literature and Sociology. Paris, Université Paris 3 Sorbonne Nouvelle.

Roselli Mariangela \& Perrenoud Marc (2010). Du lecteur à l'usager. Ethnographie d'une bibliothèque universitaire. Toulouse, Presses universitaires du Mirail.

WACQUANT LoÏc (2004) [2002]. Body and Soul. Ethnographic Notebooks of An Apprentice Boxer. New York, Oxford University Press.

ZERBIB Olivier (2014). "Le livre numérique, une offre documentaire en voie d'apparition. Interrogations, anticipations et innovations dans les bibliothèques publiques de I'Isère." Études de communication, 43: 92-93. 